\title{
UK Renal Registry 16th Annual Report: Chapter 2 UK RRT Prevalence in 2012: National and Centre-specific Analyses
}

\author{
Catriona Shaw ${ }^{a}$, David Pitcher ${ }^{a}$, Rishi Pruthi $^{a}$, Damian Fogarty ${ }^{\text {ab }}$

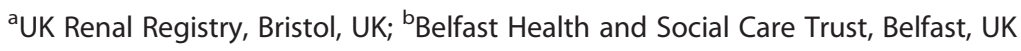

\section{Key Words}

Chronic kidney disease - Comorbidity - Diabetes - Dialysis . End stage renal disease - Established renal failure - Ethnicity - Haemodialysis - Peritoneal dialysis - Prevalence - Primary Care Trust - Renal replacement therapy - Transplantation . Treatment modality

\begin{abstract}
Introduction: This chapter describes the characteristics of adult patients on renal replacement therapy (RRT) in the UK in 2012. Methods: Data were electronically collected from all 71 renal centres within the UK. A series of crosssectional and longitudinal analyses were performed to describe the demographics of prevalent RRT patients in 2012 at centre and national level. Results: There were 54,824 adult patients receiving RRT in the UK on 31st December 2012. The UK adult prevalence of RRT was $861 \mathrm{pmp}$. This represented an annual increase in absolute prevalent numbers of approximately $3.7 \%$, although there was variation between centres and Primary Care and Health
\end{abstract}

Board areas. The actual number of patients increased across all modalities: $2.3 \%$ haemodialysis (HD), $0.3 \%$ peritoneal dialysis (PD) and $5.6 \%$ for those with a functioning transplant. The number of patients receiving home HD has increased by $19.3 \%$ since 2011 . Median RRT vintage for patients on HD was 3.4 years, PD 1.7 years and for those patients with a transplant, 10.2 years. The median age of prevalent patients was 58 years (HD 66 years, PD 63 years, transplant 52 years) compared to 55 years in 2005. For all ages the prevalence rate in men exceeded that in women. The most common recorded renal diagnosis was glomerulonephritis (biopsy proven/not biopsy proven) (18.8\%). Transplantation was the most common treatment modality (50.4\%) Conclusions: The HD and transplant population continued to expand; the decline in the size of the prevalent PD population has plateaued. There were national, regional and dialysis centre level variations in prevalence rates. Prevalent patients were on average three years older than the prevalent RRT cohort 7 years ago. This has continued implications for service planning and ensuring equity of care for RRT patients.

$\begin{array}{ll}\text { KARGER } & \text { C 2014 S. Karger AG, Basel } \\ \text { Fax +4161306 1234 } & \text { 1160-2110/14/1254-0029\$38.00/0 } \\ \begin{array}{l}\text { E-Mail karger@karger.com } \\ \text { www.karger.com }\end{array} & \begin{array}{l}\text { Accessible online at: } \\ \text { www.karger.com/nec }\end{array}\end{array}$

Catriona Shaw

UK Renal Registry, Southmead Hospital, Southmead Road, Bristol, BS10 5NB, UK

Email: renalregistry@renalregistry.nhs.uk 


\section{Introduction}

This chapter presents data on all adult patients on RRT in the UK at the end of 2012. The UK Renal Registry (UKRR) received data returns for 2012 from all five renal centres in Wales, all five in Northern Ireland and all 52 in England. Data from all nine centres in Scotland were obtained from the Scottish Renal Registry. Demographic data on children and young adults can be found in chapter 7 .

These analyses of prevalent RRT patients are performed annually to aid clinicians and policy makers in planning future RRT requirements in the UK. It is important to understand national, regional and centre level variation in numbers of prevalent patients as part of the planning process. In addition, knowledge about variation in case mix is also reported to improve understanding of where resources should be focussed to improve equity of provision of RRT in the UK.

The term established renal failure (ERF) used within this chapter is synonymous with the terms end stage renal failure and end stage renal disease, which are in more widespread international usage. Patients have disliked the term 'end stage' which reflects the inevitable outcome of this disease.

\section{Methods}

These analyses relate to the prevalent RRT cohort in the UK in 2012. The cohort was defined as all adult patients receiving RRT on the UKRR database on 31st December 2012. Population estimates were obtained from the UK Office for National Statistics (ONS) [1], the National Records of Scotland (NRS) [2] and the Northern Ireland Statistic and Research Agency (NISRA) [3].

The number of adult prevalent RRT patients was calculated for the UK as a whole and for each UK country, using UKRR data from all renal centres. Crude prevalence rates were calculated per million population ( $\mathrm{pmp}$ ) and standardised prevalence ratios were calculated as detailed in appendix D: Methodology used for Analyses (www.renalreg.com) for Primary Care Trusts (PCTs) in England, Health \& Social Care Areas in Northern Ireland, Local Health Boards in Wales and Health Boards in Scotland. These areas will be referred to in this report as 'PCT/HBs' reflecting the period of time before re-organisation of PCTs in England. Briefly, data from all areas were used to calculate overall age and gender specific prevalence rates. The age and gender breakdown of the population in each $\mathrm{PCT} / \mathrm{HB}$ were obtained from the mid-2011 population estimate based on 2011 Census data from the ONS [1], the NRS [2] and the NISRA [3]. The population breakdown and the overall prevalence rates were used to calculate the expected age and gender specific prevalence numbers for each $\mathrm{PCT} / \mathrm{HB}$ for each of the last six years. The age and gender standardised prevalence ratio was the observed prevalence number divided by the expected prevalence number. The expected number of prevalent patients in a specific age/sex group (e.g. females 70-74) for a PCT is found by multiplying the total number of people (from the census) in that age/sex group in that PCT by the overall rate in the whole of the UK for that same age/sex group. Summing together the expected numbers in each of the age/sex groups gives the overall expected number of prevalent patients for that PCT. A ratio below 1 indicates that the observed number was less than expected given the area's population structure. This was statistically significant at the 5\% level if the upper confidence limit was less than 1. To enable assessment of whether a centre was an outlier in this regard, funnel plots for smaller and larger populations have been included (appendix D: figures D3, D4) which show the 95\% confidence intervals around the national average prevalence. The proportion of non-Whites in each PCT/HB was obtained from the ONS [1], the NRS [2] and the NISRA [3].

The prevalence rate per million population for each centre was calculated using a derived catchment population. For a full description of the methodology used to estimate the catchment populations see appendix E: Methodology for Estimating Catchment Populations Analyses (www.renalreg.com). For Scotland, mid-2011 populations of Health Boards (from the General Register Office for Scotland) were converted to centre level populations using an approximate mapping of renal centres to HBs supplied by the Scottish Renal Registry. Estimates of the catchment populations in Northern Ireland were supplied by personal communication from Dr D Fogarty.

Throughout this chapter, haemodialysis refers to all modes of HD treatment, including haemodiafiltration (HDF). Several centres reported significant numbers of patients on HDF, but other centres did not differentiate this treatment type in their UKRR returns. Where joint care of renal transplant recipients between the referring centre and the transplant centre occurred, the patient was allocated to the centre which saw the patient most frequently, usually the referring centre. Thus the number of patients allocated to a transplant centre is often lower than that recorded by the centre itself and as a converse pre-emptively transplanted patients are sometimes allocated to the transplanting centre rather than the referring centre if no transfer out code had been sent through. Queries and updated information are welcomed by the UKRR at any point during the year if this has occurred.

Prevalent patients on RRT in 2012 were examined by time on RRT, age group, gender, ethnic origin, primary renal disease, presence of diabetes and treatment modality (see appendix $\mathrm{H}$ : Coding (www.renalreg.com)). In this year's analysis of prevalence, only adult patients on RRT contributed to the numerator. In previous years, children have also been included in the numerator. Data on the paediatric population are presented in chapter 7 . Some centres electronically upload ethnicity coding to their renal information technology (IT) system from the hospital Patient Administration System (PAS). Ethnicity coding in these PAS systems is based on self-reported ethnicity and uses a different coding system to those centres not linked to PAS [4]. For the remaining centres, ethnicity coding is performed by clinical staff and recorded directly into the renal IT system (using a variety of coding systems). For all these analyses, data on ethnic origin were grouped into Whites, South Asians, Blacks, Chinese and 
Table 2.1. Prevalence of adult RRT in the UK on $31 / 12 / 2012$

\begin{tabular}{|c|c|c|c|c|c|}
\hline & England & $\mathrm{N}$ Ireland & Scotland & Wales & UK \\
\hline All UK centres & 46,076 & 1,520 & 4,492 & 2,736 & 54,824 \\
\hline Total estimated population, mid-2012 (millions) ${ }^{*}$ & 53.5 & 1.8 & 5.3 & 3.1 & 63.7 \\
\hline Prevalence rate PD (pmp) & 61 & 46 & 44 & 65 & 60 \\
\hline Prevalence rate dialysis (pmp) & 430 & 427 & 405 & 416 & 427 \\
\hline Prevalence rate transplant (pmp) & 432 & 407 & 440 & 474 & 434 \\
\hline
\end{tabular}

*Data from the Office for National Statistics, National Records of Scotland and the Northern Ireland Statistics and Research Agency - based on the 2011 census

Others as described in appendix H: Coding (www.renalreg.com). Time on RRT was defined as median time on treatment and was calculated from the most recent start date. Patients without an accurate start date were excluded from this calculation. Analyses were done for the UK as a whole, by UK country, at centre level and split by treatment modality when appropriate.

Chi-squared test, Fisher's exact test, linear regression and Kruskal Wallis tests were used as appropriate to test for significant differences between groups. The data were analysed using SAS 9.3.

\section{Results}

Prevalent patient numbers and changes in prevalence

The number of patients for each country (table 2.1) was calculated by adding the patient numbers in each renal centre and these differ marginally from those quoted elsewhere when patients are allocated to geographical areas by their individual postcodes, as some centres treat patients across national boundaries.

There were 54,824 adult patients receiving RRT in the UK at the end of 2012, giving an adult UK population prevalence of $861 \mathrm{pmp}$ (table 2.1) compared with $841 \mathrm{pmp}$ in 2011. Prevalence rates increased in all of the UK countries in 2012. PD prevalence increased in Northern Ireland but remained static or decreased in the other three countries compared with 2011. The decline in PD prevalence in the UK overall noted since 1997 seems to have plateaud in 2011 and 2012 with a static overall prevalence of $60 \mathrm{pmp}$. Once more, the prevalence of transplanted patients increased in the UK. Northern Ireland had a higher RRT prevalence rate for patients aged 65 and older compared with the other UK countries (figure 2.1). In the UK, the RRT prevalence rate in patients aged 80-84 continued to rise over time from 1,824 per million age related population (pmarp) in 2011 to 1,896 pmarp in 2012 and in patients aged $>85$ years from 952 pmarp in 2011 to
983 pmarp in 2012. It is likely that this ageing of the prevalent population was due to an increasing number of older patients starting RRT, although improving patient survival will also contribute.

\section{Prevalent patients by RRT modality and centre}

The number of prevalent patients in each renal centre and the distribution of their treatment modalities varied widely (table 2.2). Many factors including geography, local population density, age distribution, ethnic composition, prevalence of diseases predisposing to kidney disease and the social deprivation index of that population may contribute to this.

\section{Changes in prevalence}

Overall growth in the prevalent UK RRT population from 2011 to 2012 was $3.7 \%$ (table 2.3), an annual growth rate which has been fairly consistent over the last 10-15 years (figure 2.2). Most of the growth in the prevalent RRT population was due to a continued increase in the size of the prevalent RRT population in England, Wales

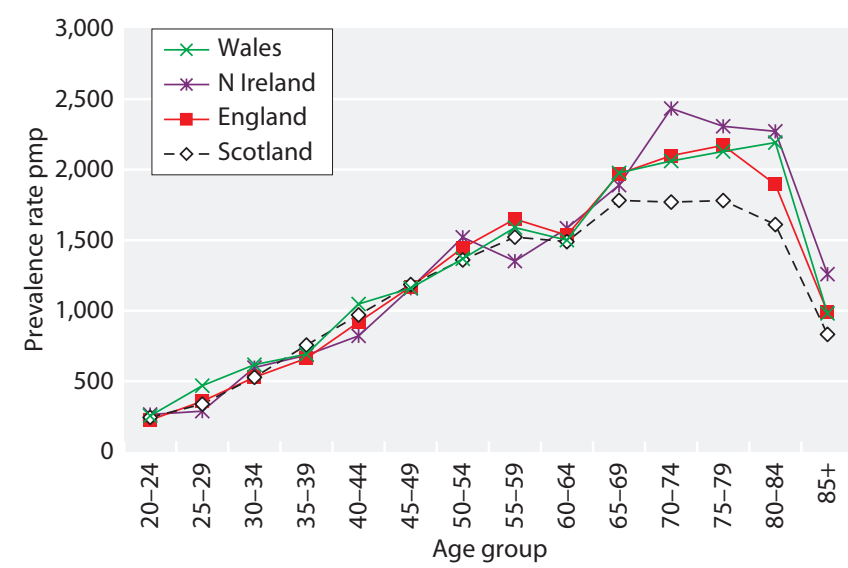

Fig. 2.1. Prevalence rates per million population by age group and UK country on $31 / 12 / 2012$ 
Table 2.2. Number of prevalent RRT patients by treatment modality and centre on $31 / 12 / 2012$

\begin{tabular}{|c|c|c|c|c|c|c|c|c|}
\hline Centre & $\mathrm{HD}$ & $\mathrm{PD}$ & Dialysis & Transplant & RRT & $\begin{array}{l}\text { Catchment } \\
\text { population } \\
\text { (millions) }\end{array}$ & $\begin{array}{l}2012 \\
\text { crude rate } \\
\text { pmp }\end{array}$ & $(95 \% \mathrm{CI})$ \\
\hline B Heart & 435 & 47 & 482 & 188 & 670 & 0.74 & 908 & $(839-977)$ \\
\hline $\mathrm{B} \mathrm{QEH}^{\mathrm{a}}$ & 926 & 159 & 1,085 & 886 & 1,971 & 1.70 & 1,160 & $(1,109-1,211)$ \\
\hline Basldn & 164 & 32 & 196 & 68 & 264 & 0.42 & 636 & $(559-713)$ \\
\hline Bristol $^{\mathrm{a}}$ & 494 & 66 & 560 & 777 & 1,337 & 1.44 & 929 & (879-979) \\
\hline $\mathrm{Camb}^{\mathrm{a}}$ & 350 & 35 & 385 & 728 & 1,113 & 1.16 & 961 & $(905-1,018)$ \\
\hline Carlis & 61 & 27 & 88 & 128 & 216 & 0.32 & 673 & $(584-763)$ \\
\hline Carsh & 764 & 112 & 876 & 599 & 1,475 & 1.91 & 771 & $(732-811)$ \\
\hline Chelms & 129 & 26 & 155 & 69 & 224 & 0.51 & 439 & $(381-496)$ \\
\hline Dorset & 260 & 48 & 308 & 302 & 610 & 0.86 & 708 & $(652-764)$ \\
\hline Dudley & 169 & 63 & 232 & 84 & 316 & 0.44 & 715 & $(636-794)$ \\
\hline Exeter & 397 & 77 & 474 & 372 & 846 & 1.09 & 777 & (724-829) \\
\hline Glouc & 219 & 36 & 255 & 162 & 417 & 0.59 & 710 & $(642-778)$ \\
\hline Hull & 334 & 90 & 424 & 365 & 789 & 1.02 & 773 & $(719-827)$ \\
\hline Ipswi & 129 & 31 & 160 & 179 & 339 & 0.40 & 850 & $(759-940)$ \\
\hline Kent & 384 & 62 & 446 & 476 & 922 & 1.22 & 753 & $(704-802)$ \\
\hline L Barts ${ }^{a}$ & 895 & 195 & 1,090 & 865 & 1,955 & 1.83 & 1,068 & $(1,021-1,116)$ \\
\hline L Guys $^{\mathrm{a}}$ & 626 & 31 & 657 & 1,088 & 1,745 & 1.08 & 1,612 & $(1,537-1,688)$ \\
\hline L Kings & 492 & 86 & 578 & 340 & 918 & 1.17 & 784 & $(733-834)$ \\
\hline L Rfree ${ }^{a}$ & 714 & 120 & 834 & 1,031 & 1,865 & 1.52 & 1,228 & $(1,173-1,284)$ \\
\hline $\mathrm{Newc}^{\mathrm{a}}$ & 285 & 47 & 332 & 614 & 946 & 1.12 & 844 & (790-898) \\
\hline Norwch & 318 & 55 & 373 & 239 & 612 & 0.79 & 778 & $(716-840)$ \\
\hline Nottm $^{a}$ & 376 & 81 & 457 & 549 & 1,006 & 1.09 & 925 & $(868-982)$ \\
\hline Oxford $^{\mathrm{a}}$ & 423 & 86 & 509 & 1,026 & 1,535 & 1.69 & 908 & (863-953) \\
\hline Plymth $^{\mathrm{ab}}$ & 131 & 35 & 166 & 293 & 459 & 0.47 & 977 & $(888-1,067)$ \\
\hline Ports $^{\mathrm{a}}$ & 555 & 83 & 638 & 809 & 1,447 & 2.02 & 715 & $(678-752)$ \\
\hline Prestn & 536 & 69 & 605 & 476 & 1,081 & 1.49 & 724 & $(681-767)$ \\
\hline Redng & 271 & 72 & 343 & 328 & 671 & 0.91 & 737 & $(682-793)$ \\
\hline Salford & 380 & 104 & 484 & 398 & 882 & 1.49 & 592 & $(553-631)$ \\
\hline Sheff $^{\mathrm{a}}$ & 588 & 69 & 657 & 650 & 1,307 & 1.37 & 953 & $(901-1,005)$ \\
\hline Shrew & 195 & 41 & 236 & 118 & 354 & 0.50 & 707 & $(633-781)$ \\
\hline Stevng & 409 & 32 & 441 & 224 & 665 & 1.20 & 552 & $(510-594)$ \\
\hline Sthend & 118 & 14 & 132 & 81 & 213 & 0.32 & 672 & $(582-763)$ \\
\hline Stoke & 305 & 79 & 384 & 311 & 695 & 0.89 & 781 & $(723-839)$ \\
\hline Sund & 198 & 22 & 220 & 201 & 421 & 0.62 & 681 & $(616-746)$ \\
\hline Truro & 154 & 23 & 177 & 200 & 377 & 0.41 & 913 & $(820-1,005)$ \\
\hline Wirral & 202 & 32 & 234 & & 234 & 0.57 & 409 & $(357-462)$ \\
\hline Wolve & 285 & 92 & 377 & 151 & 528 & 0.67 & 790 & $(722-857)$ \\
\hline York & 135 & 32 & 167 & 229 & 396 & 0.49 & 805 & $(725-884)$ \\
\hline
\end{tabular}


Table 2.2. Continued

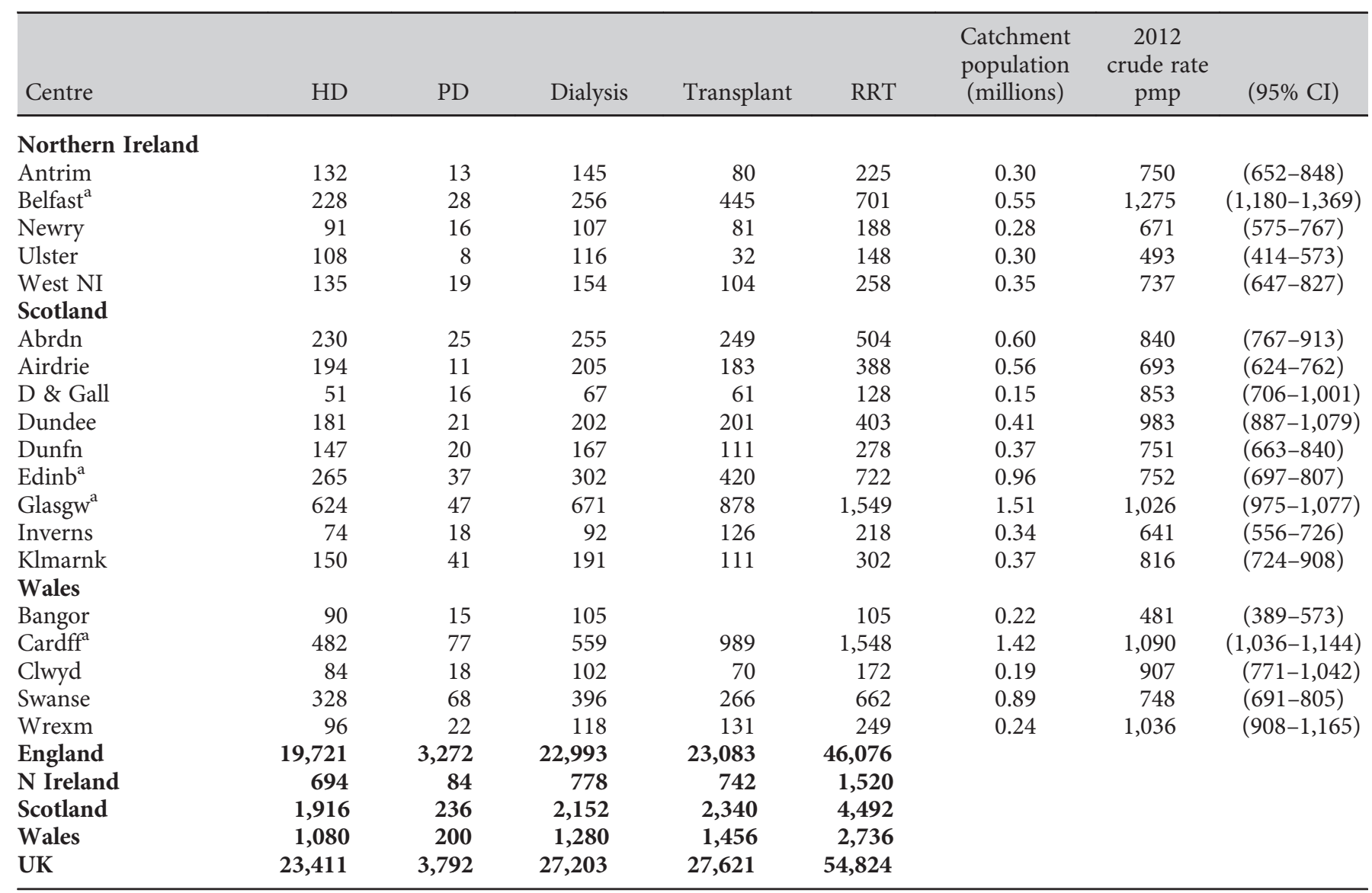

Blank cells indicate no patients on that treatment type attending that centre when data were collected

Centres prefixed 'L' are London centres

The numbers of patients calculated for each country quoted above differ marginally from those quoted elsewhere when patients are allocated to areas by their individual post codes, as some centres treat patients from across national boundaries

${ }^{\text {a Transplant centres }}$

${ }^{\mathrm{b}}$ The catchment population for Plymouth may be too low, see appendix E

and Scotland, with slower growth in the prevalent RRT population in Northern Ireland. The increases in prevalence across Scotland and England were similar at $\sim 4 \%$. The increase in prevalence in Wales was 2.4\%. In Northern Ireland the increase in the prevalent RRT population was lower in magnitude at 1.5\% between 2011 and 2012.

From 2011 to 2012, there was a $0.7 \%$ pmp growth in prevalent HD patients, a $4.3 \%$ pmp growth in those with a functioning transplant and a $1.5 \% \mathrm{pmp}$ decline in patients on PD. Between 2007 and 2012 there was an average annual $2.6 \%$ pmp growth in $\mathrm{HD}, 4.8 \%$ pmp fall in $\mathrm{PD}$, and $4.6 \% \mathrm{pmp}$ growth in prevalent transplant patients in the UK (table 2.4). In the same period there was an average annual $16.8 \%$ pmp growth in the use of home haemodialysis (data not shown).

Prevalence rates between centres showed marked variation (table 2.2); the long-term (1997-2012) UK prevalence pattern by treatment modality is shown in figure 2.2. The steady growth in transplant numbers was maintained in 2012. The increase in haemodialysis patient numbers has been associated with an increase in home haemodialysis, from $2.0 \%$ of the dialysis population in 2007 to $4.0 \%$ in 2012 . The slow contraction in PD observed in more recent years may have started to plateau in 2012, with only a small reduction in the prevalent PD population from $7.2 \%$ in 2011 to $6.9 \%$ in 2012.

Prevalence of RRT in Primary Care Trusts in England, Health and Social Care Areas in Northern Ireland (HBs), Local Health Boards in Wales (HBs) and Health Boards in Scotland (HBs)

The need for RRT depends on many factors such as predisposing conditions but also on social and 
Table 2.3. Number of prevalent patients on RRT by centre at year end 2008-2012

\begin{tabular}{|c|c|c|c|c|c|c|c|}
\hline \multirow[b]{2}{*}{ Centre } & \multicolumn{5}{|c|}{ Date } & \multirow{2}{*}{$\begin{array}{c}\% \text { change } \\
2011-2012\end{array}$} & \multirow{2}{*}{$\begin{array}{l}\% \text { annual cl } \\
2008-20\end{array}$} \\
\hline & $31 / 12 / 2008$ & $31 / 12 / 2009$ & $31 / 12 / 2010$ & $31 / 12 / 2011$ & $31 / 12 / 2012$ & & \\
\hline \multicolumn{8}{|l|}{ England } \\
\hline B Heart & 598 & 624 & 633 & 664 & 670 & 0.9 & 2.9 \\
\hline B QEH & 1,714 & 1,821 & 1,844 & 1,912 & 1,971 & 3.1 & 3.6 \\
\hline Basldn & 217 & 214 & 214 & 233 & 264 & 13.3 & 5.0 \\
\hline Bradfd & 414 & 422 & 455 & 467 & 508 & 8.8 & 5.2 \\
\hline Brightn & 722 & 737 & 770 & 775 & 831 & 7.2 & 3.6 \\
\hline Bristol & 1,247 & 1,232 & 1,261 & 1,315 & 1,337 & 1.7 & 1.8 \\
\hline Camb & 927 & 940 & 1,004 & 1,074 & 1,113 & 3.6 & 4.7 \\
\hline Carlis & 205 & 205 & 206 & 215 & 216 & 0.5 & 1.3 \\
\hline Carsh & 1,249 & 1,302 & 1,377 & 1,380 & 1,475 & 6.9 & 4.2 \\
\hline Chelms & 207 & 225 & 238 & 216 & 224 & 3.7 & 2.0 \\
\hline Colchr & 118 & 116 & 120 & 119 & 117 & -1.7 & -0.2 \\
\hline Covnt & 745 & 794 & 844 & 874 & 900 & 3.0 & 4.8 \\
\hline Derby & 389 & 419 & 459 & 448 & 477 & 6.5 & 5.2 \\
\hline Donc & 154 & 196 & 222 & 248 & 261 & 5.2 & 14.1 \\
\hline Dorset & 515 & 553 & 585 & 586 & 610 & 4.1 & 4.3 \\
\hline Dudley & 275 & 292 & 303 & 284 & 316 & 11.3 & 3.5 \\
\hline Exeter & 708 & 731 & 785 & 796 & 846 & 6.3 & 4.6 \\
\hline Glouc & 325 & 366 & 377 & 381 & 417 & 9.4 & 6.4 \\
\hline Hull & 696 & 725 & 725 & 757 & 789 & 4.2 & 3.2 \\
\hline Ipswi & 294 & 312 & 316 & 340 & 339 & -0.3 & 3.6 \\
\hline Kent & 714 & 744 & 797 & 864 & 922 & 6.7 & 6.6 \\
\hline L Barts & 1,526 & 1,638 & 1,778 & 1,872 & 1,955 & 4.4 & 6.4 \\
\hline L Guys & 1,447 & 1,613 & 1,625 & 1,681 & 1,745 & 3.8 & 4.8 \\
\hline L Kings & 784 & 786 & 837 & 858 & 918 & 7.0 & 4.0 \\
\hline L Rfree & 1,510 & 1,546 & 1,639 & 1,727 & 1,865 & 8.0 & 5.4 \\
\hline L St.G & 624 & 663 & 684 & 716 & 724 & 1.1 & 3.8 \\
\hline L West & 2,576 & 2,734 & 2,879 & 3,020 & 3,104 & 2.8 & 4.8 \\
\hline Leeds & 1,342 & 1,348 & 1,383 & 1,425 & 1,416 & -0.6 & 1.4 \\
\hline Leic & 1,660 & 1,737 & 1,809 & 1,927 & 1,982 & 2.9 & 4.5 \\
\hline Liv Ain & 130 & 147 & 159 & 189 & 195 & 3.2 & 10.7 \\
\hline Liv RI & 1,200 & 1,223 & 1,238 & 1,250 & 1,241 & -0.7 & 0.8 \\
\hline M RI & 1,424 & 1,450 & 1,552 & 1,646 & 1,710 & 3.9 & 4.7 \\
\hline Middlbr & 682 & 707 & 711 & 752 & 789 & 4.9 & 3.7 \\
\hline Newc & 901 & 898 & 900 & 917 & 946 & 3.2 & 1.2 \\
\hline Norwch & 567 & 591 & 615 & 611 & 612 & 0.2 & 1.9 \\
\hline Nottm & 955 & 975 & 1,008 & 1,019 & 1,006 & -1.3 & 1.3 \\
\hline Oxford & 1,318 & 1,343 & 1,421 & 1,446 & 1,535 & 6.2 & 3.9 \\
\hline Plymth & 443 & 456 & 461 & 465 & 459 & -1.3 & 0.9 \\
\hline Ports & 1,268 & 1,301 & 1,333 & 1,394 & 1,447 & 3.8 & 3.4 \\
\hline Prestn & 876 & 940 & 970 & 1,011 & 1,081 & 6.9 & 5.4 \\
\hline Redng & 578 & 618 & 636 & 688 & 671 & -2.5 & 3.8 \\
\hline Salford & 758 & 784 & 837 & 820 & 882 & 7.6 & 3.9 \\
\hline Sheff & 1,216 & 1,216 & 1,254 & 1,260 & 1,307 & 3.7 & 1.8 \\
\hline Shrew & 325 & 337 & 343 & 342 & 354 & 3.5 & 2.2 \\
\hline Stevng & 580 & 582 & 606 & 639 & 665 & 4.1 & 3.5 \\
\hline Sthend & 204 & 207 & 212 & 207 & 213 & 2.9 & 1.1 \\
\hline Stoke & 603 & 643 & 658 & 696 & 695 & -0.1 & 3.6 \\
\hline Sund & 343 & 368 & 369 & 388 & 421 & 8.5 & 5.3 \\
\hline Truro & 297 & 320 & 335 & 352 & 377 & 7.1 & 6.1 \\
\hline Wirral & 216 & 223 & 223 & 234 & 234 & 0.0 & 2.0 \\
\hline Wolve & 490 & 490 & 531 & 513 & 528 & 2.9 & 1.9 \\
\hline York & 276 & 321 & 338 & 340 & 396 & 16.5 & 9.4 \\
\hline
\end{tabular}


Table 2.3. Continued

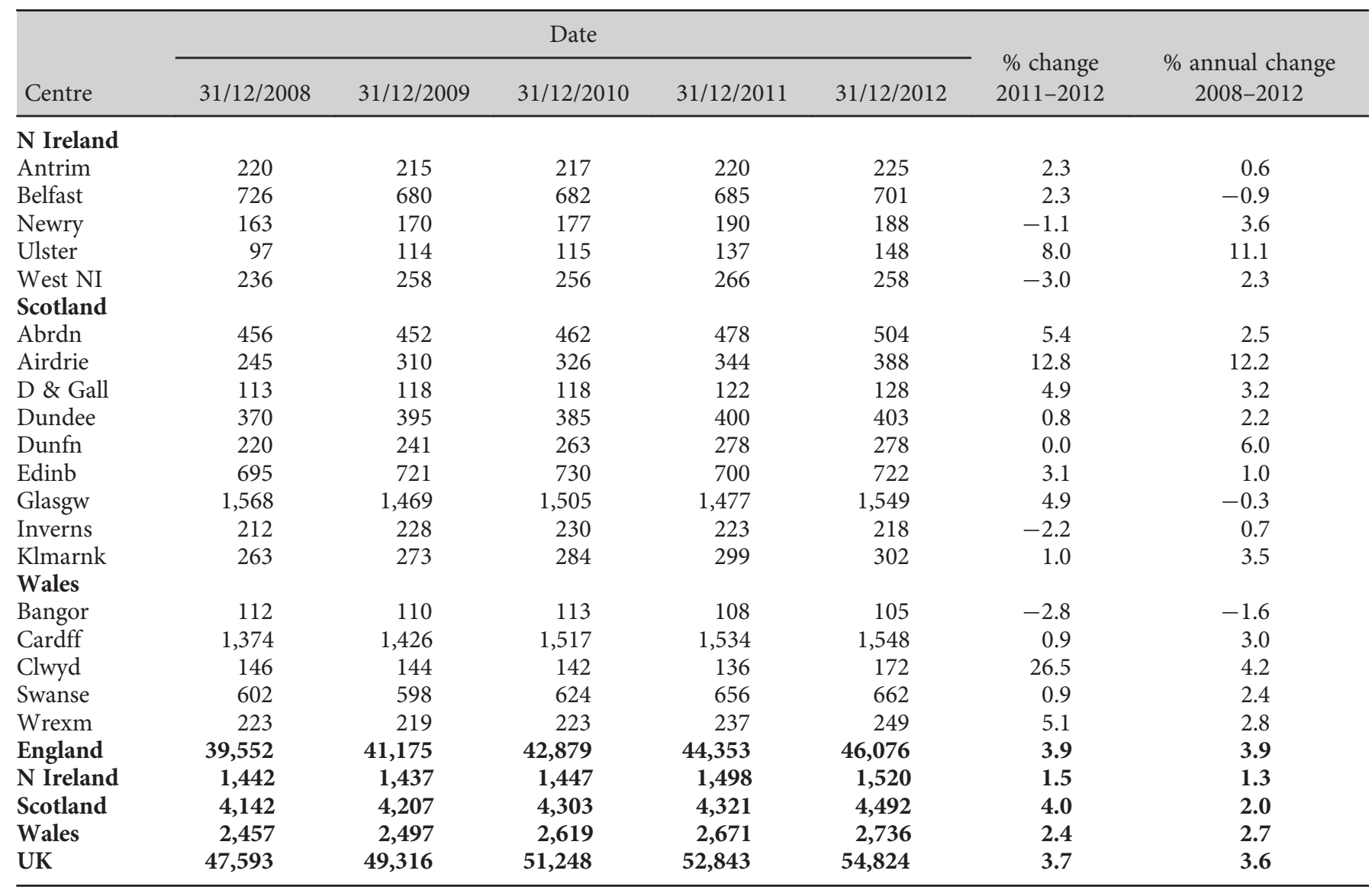

demographic factors such as age, gender, social deprivation and ethnicity. Hence, comparison of crude prevalence rates by geographical area can be misleading. This section, as in previous reports, uses age and gender stan-

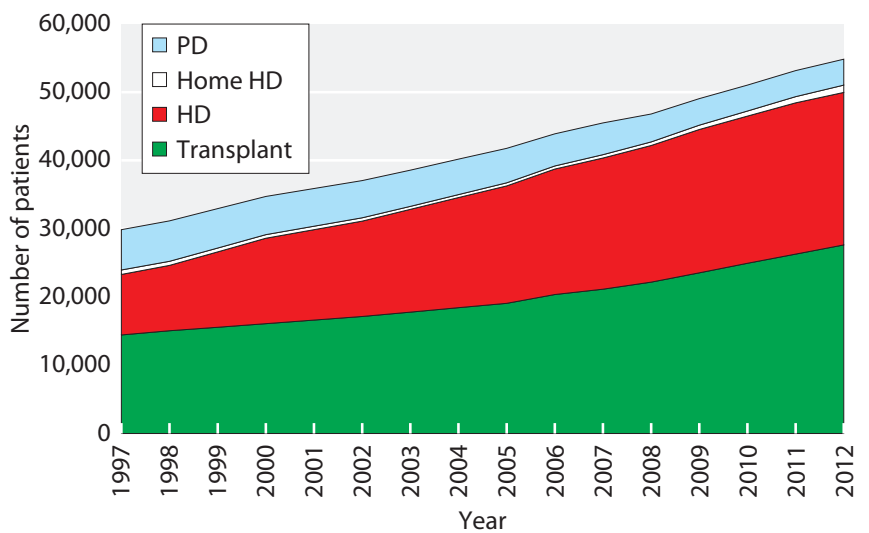

Fig. 2.2. Growth in prevalent patients by treatment modality at the end of each year 1997-2012 dardisation to compare RRT prevalence rates. The ethnic minority profile is also provided to help understand the differences in standardised prevalence ratios (SPRs). The impact of social deprivation was reported in the 2003 UKRR Report [4].

There were substantial variations in the crude PCT/ $\mathrm{HB}$ prevalence rates pmp, from $430 \mathrm{pmp}$ (Shetland, population 23,200 ) to $1,630 \mathrm{pmp}$ (Brent, population $312,200)$. There were similar variations in the standardised prevalence ratios (ratio of observed:expected prevalence rate given the age/gender breakdown of the PCT/ HB) from 0.48 (Shetland) to 2.23 (Brent) (table 2.5). Confidence intervals are not presented for the rates per million population for 2012 but figures D3 and D4 in appendix D (www.renalreg.com) can be used to determine if a PCT/HB falls within the range representing the $95 \%$ confidence limit of the national average prevalence rate. The annual standardised prevalence ratios were inherently more stable than the annual standardised incidence ratios (chapter 1). 
Table 2.4. Change in RRT prevalence rates pmp 2007-2012 by modality*

\begin{tabular}{|c|c|c|c|c|c|c|c|c|c|c|}
\hline \multirow[b]{2}{*}{ Year } & \multicolumn{5}{|c|}{ Prevalence } & \multicolumn{5}{|c|}{$\%$ growth in prevalence $\mathrm{pmp}$} \\
\hline & HD pmp & PD pmp & Dialysis pmp & Transplant pmp & RRT pmp & $\mathrm{HD}$ & $\mathrm{PD}$ & Dialysis & $\mathrm{Tx}$ & RRT \\
\hline 2008 & 342 & 69 & 411 & 363 & 774 & 5.8 & -9.0 & 2.9 & 4.9 & 3.8 \\
\hline 2009 & 354 & 64 & 417 & 377 & 794 & 3.5 & -7.8 & 1.6 & 3.7 & 2.6 \\
\hline 2010 & 359 & 62 & 421 & 397 & 818 & 1.5 & -3.2 & 0.8 & 5.4 & 3.0 \\
\hline \multicolumn{6}{|c|}{ Average annual growth $2007-2012$} & 2.6 & -4.8 & 1.4 & 4.6 & 2.9 \\
\hline
\end{tabular}

${ }^{*}$ Differences in the figures for dialysis and RRT prevalence and the sum of the separate modalities are due to rounding pmp - per million population

Tx $=$ transplant

Factors associated with variation in standardised prevalence ratios in Primary Care Trusts in England, Health and Social Care Areas in Northern Ireland, Local Health Boards in Wales and Health Boards in Scotland

In 2012, there were $57 \mathrm{PCT} / \mathrm{HBs}$ with a significantly low SPR, 73 with a 'normal' SPR and 47 with a significantly high SPR (table 2.5). The areas with high and low SPRs have been fairly consistent over the last few years. They tend to reflect the demographics of the regions in question such that urban, ethnically diverse populations in areas of high social deprivation have the highest prevalence rates of renal replacement therapy. Mean SPRs were significantly higher in the 75 PCT/ HBs with an ethnic minority population greater than $10 \%$ than in those with lower ethnic minority populations $(p<0.001)$. The SPR was positively correlated with the percentage of the population that are non-White $(\mathrm{r}=0.69 \mathrm{p}<0.001)$. In 2012 for each $10 \%$ increase in ethnic minority population, the standardised prevalence ratio increased by 0.16 (equates to $\sim 16 \%$ ). In figure 2.3 , the relationship between the ethnic composition of a $\mathrm{PCT} / \mathrm{HB}$ and its SPR is demonstrated.

Only five of the $102 \mathrm{PCT} / \mathrm{HBs}$ with ethnic minority populations of less than $10 \%$ had high SPRs: Abertawe Bro Morgannwg University, Aneurin Bevan, Belfast, Cwm Taf, and Greater Glasgow \& Clyde. Forty-two (56\%) of the 75 PCT/HBs with ethnic minority populations greater than $10 \%$ had high SPRs, whereas seven (9\%) (Bedfordshire, Brighton and Hove City, Buckinghamshire, Hertfordshire, Leeds, Richmond \& Twickenham and Trafford) had low SPRs. However, not all PCT/HBs with a high $(>15 \%)$ ethnic minority population also had higher than expected RRT prevalence rates (e.g. Bromley, Oldham, Kensington). The age and gender standardised prevalence ratios in each region of England and in Wales, Northern Ireland and Scotland are presented in table 2.6. These calculations have not taken into account variation in ethnicity between areas. Wales and Northern Ireland previously had higher than expected prevalence rates but in more recent years were similar to their expected rates. Scotland had lower than expected prevalence rates of RRT. There was marked variation (20-fold) in prevalence rates in over 80 year olds between PCT/HBs (data not shown).

\section{Case mix in prevalent $R R T$ patients}

Time on RRT (vintage)

Table 2.7 shows the median time, in years, since starting RRT of prevalent RRT patients on 31st December 2012. Median time on RRT for all prevalent patients remained fairly static at 5.9 years. Patients with functioning transplants had survived a median of 10.2 years on RRT whilst the median time on RRT of HD and PD patients was significantly less (3.4 and 1.7 years respectively, $\mathrm{p}<0.001$ ).

\section{Age}

The median age of prevalent UK patients on RRT at 31st December 2012 was static (58.3 years) compared with 2011 (58.2 years) (table 2.8) and significantly higher than in 2005 when it was 55 years. There were marked differences between modalities; the median age of HD patients (66.4 years) was greater than that of those on PD (63.4 years) and substantially higher than that of transplanted patients (52.3 years). Half of the UK prevalent RRT population was in the 40-64 years age group (table 2.9). The proportion of patients aged 75 years and older was $17.1 \%$ in Wales, $16.1 \%$ in Northern Ireland, $15.7 \%$ in England and 13.4\% in Scotland 
Table 2.5. Prevalence of RRT and standardised prevalence ratios in PCT/HB areas

PCT/HB - PCT in England, Health and Social Care Areas in Northern Ireland, Local Health Boards in Wales and Health Boards in Scotland $\mathrm{O} / \mathrm{E}$ - standardised prevalence ratio. Ratio of observed:expected rate of RRT given the age and gender breakdown of the area

LCL - lower 95\% confidence limit

UCL - upper 95\% confidence limit

pmp - per million population

Blank cells - no data returned to the UKRR for that year

Areas with significantly low prevalence ratios in 2012 are italicised in greyed areas, those with significantly high prevalence ratios in 2012 are bold in greyed areas

Population data from the Office for National Statistics, National Records of Scotland and the Northern Ireland Statistics and Research Agency based on the 2011 Census

$\%$ non-White - percentage of the PCT/HB population that is non-White, from 2011 Census for E, W \& NI (2001 for Scotland)

ONS specifies that the populations should be rounded to the nearest 100 when being presented

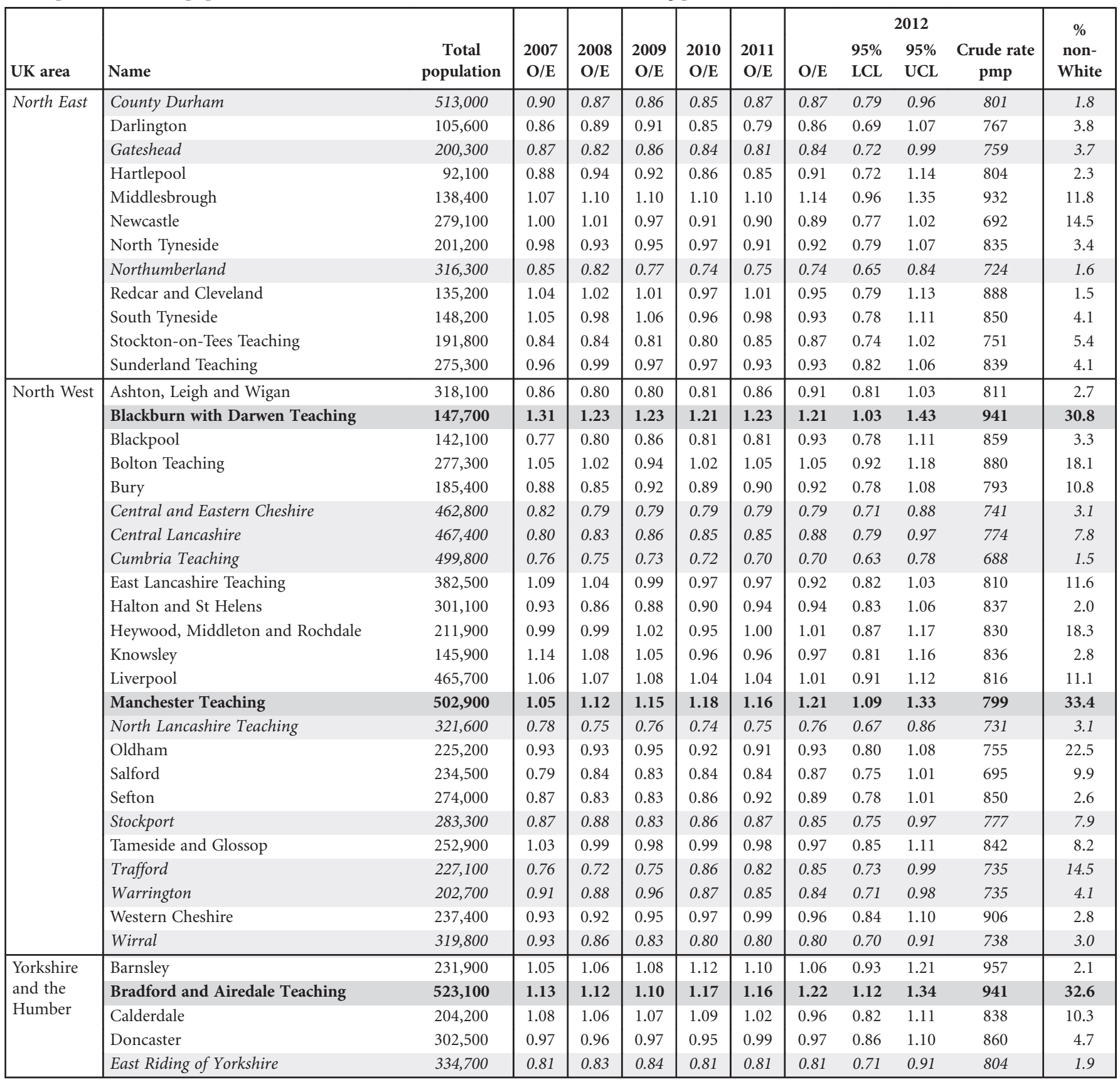


Table 2.5. Continued

\begin{tabular}{|c|c|c|c|c|c|c|c|c|c|c|c|c|}
\hline UK area & Name & $\begin{array}{c}\text { Total } \\
\text { population }\end{array}$ & $\begin{array}{l}2007 \\
\mathrm{O} / \mathrm{E}\end{array}$ & $\begin{array}{c}2008 \\
\mathrm{O} / \mathrm{E}\end{array}$ & $\begin{array}{c}2009 \\
\mathrm{O} / \mathrm{E}\end{array}$ & $\begin{array}{c}2010 \\
\mathrm{O} / \mathrm{E}\end{array}$ & $\begin{array}{l}2011 \\
\mathrm{O} / \mathrm{E}\end{array}$ & $\mathbf{O} / \mathbf{E}$ & $\begin{array}{l}95 \% \\
\text { LCL }\end{array}$ & $\begin{array}{c}2012 \\
95 \% \\
\text { UCL }\end{array}$ & $\begin{array}{c}\text { Crude rate } \\
\text { pmp }\end{array}$ & $\begin{array}{c}\% \\
\text { non- } \\
\text { White }\end{array}$ \\
\hline \multirow{6}{*}{$\begin{array}{l}\text { Yorkshire } \\
\text { and the } \\
\text { Humber }\end{array}$} & Kirklees & 423,000 & 1.08 & 1.01 & 1.01 & 1.02 & 1.01 & 1.02 & 0.92 & 1.13 & 856 & 20.9 \\
\hline & Leeds & 750,700 & 0.98 & 0.93 & 0.91 & 0.91 & 0.90 & 0.87 & 0.80 & 0.95 & 701 & 14.9 \\
\hline & North East Lincolnshire & 161,200 & 0.99 & 1.00 & 0.98 & 0.97 & 1.03 & 1.01 & 0.86 & 1.18 & 900 & 2.6 \\
\hline & Rotherham & 257,700 & 1.11 & 1.13 & 1.10 & 1.13 & 1.06 & 1.05 & 0.92 & 1.19 & 939 & 6.4 \\
\hline & Sheffield & 551,800 & 1.11 & 1.10 & 1.10 & 1.13 & 1.10 & 1.11 & 1.02 & 1.21 & 901 & 16.3 \\
\hline & Wakefield District & 326,400 & 0.84 & 0.81 & 0.81 & 0.81 & 0.84 & 0.86 & 0.76 & 0.97 & 772 & 4.6 \\
\hline \multirow{6}{*}{$\begin{array}{l}\text { East } \\
\text { Midlands }\end{array}$} & Bassetlaw & 113,000 & 0.97 & 0.90 & 0.80 & 0.78 & 0.78 & 0.84 & 0.68 & 1.03 & 788 & 2.6 \\
\hline & Derby City & 248,900 & 0.99 & 1.05 & 1.14 & 1.11 & 1.10 & 1.15 & 1.01 & 1.31 & 928 & 19.7 \\
\hline & Derbyshire County & 737,500 & 0.87 & 0.87 & 0.85 & 0.84 & 0.85 & 0.82 & 0.76 & 0.89 & 773 & 2.5 \\
\hline & Northamptonshire Teaching & 694,000 & 0.91 & 0.92 & 0.91 & 0.90 & 0.91 & 0.91 & 0.83 & 0.99 & 784 & 8.5 \\
\hline & Nottingham City & 303,900 & 1.15 & 1.16 & 1.20 & 1.27 & 1.21 & 1.19 & 1.05 & 1.34 & 849 & 28.5 \\
\hline & Nottinghamshire County Teaching & 673,800 & 1.00 & 0.99 & 0.96 & 0.95 & 0.95 & 0.91 & 0.84 & 0.99 & 842 & 4.8 \\
\hline \multirow{9}{*}{$\begin{array}{l}\text { West } \\
\text { Midlands }\end{array}$} & Birmingham East and North & 421,400 & 1.52 & 1.57 & 1.54 & 1.49 & 1.52 & 1.53 & 1.40 & 1.67 & 1179 & 36.1 \\
\hline & Coventry Teaching & 316,900 & 1.19 & 1.21 & 1.25 & 1.30 & 1.33 & 1.38 & 1.24 & 1.54 & 1079 & 26.2 \\
\hline & Dudley & 313,300 & 0.91 & 0.88 & 0.92 & 0.90 & 0.84 & 0.91 & 0.81 & 1.03 & 827 & 10.0 \\
\hline & Heart of Birmingham Teaching & 299,200 & 2.25 & 2.28 & 2.30 & 2.28 & 2.18 & 2.18 & 1.98 & 2.40 & 1380 & 70.5 \\
\hline & Herefordshire & 183,600 & 0.88 & 0.80 & 0.84 & 0.78 & 0.79 & 0.79 & 0.67 & 0.93 & 773 & 1.8 \\
\hline & North Staffordshire & 212,900 & 0.88 & 0.88 & 0.92 & 0.88 & 0.93 & 0.88 & 0.76 & 1.02 & 827 & 3.5 \\
\hline & Sandwell & 309,000 & 1.44 & 1.52 & 1.58 & 1.55 & 1.55 & 1.53 & 1.39 & 1.69 & 1233 & 30.1 \\
\hline & Shropshire County & 307,100 & 0.90 & 0.93 & 0.90 & 0.87 & 0.85 & 0.84 & 0.74 & 0.95 & 808 & 2.0 \\
\hline & Worcestershire & 566,600 & 0.84 & 0.84 & 0.85 & 0.85 & 0.86 & 0.87 & 0.79 & 0.95 & 819 & 4.3 \\
\hline \multirow{13}{*}{$\begin{array}{l}\text { East of } \\
\text { England }\end{array}$} & Bedfordshire & 413,500 & 0.85 & 0.87 & 0.86 & 0.88 & 0.86 & 0.88 & 0.79 & 0.99 & 771 & 11.2 \\
\hline & Cambridgeshire & 622,300 & 0.87 & 0.83 & 0.85 & 0.88 & 0.91 & 0.87 & 0.80 & 0.96 & 758 & 7.4 \\
\hline & Hertfordshire & $1,119,800$ & 0.82 & 0.91 & 0.91 & 0.93 & 0.93 & 0.92 & 0.86 & 0.98 & 780 & 12.4 \\
\hline & Great Yarmouth and Waveney & 212,800 & 0.54 & 0.82 & 0.91 & 0.97 & 0.97 & 0.93 & 0.80 & 1.07 & 902 & 2.7 \\
\hline & Luton & 203,600 & 1.21 & 1.27 & 1.26 & 1.28 & 1.35 & 1.36 & 1.18 & 1.56 & 992 & 45.3 \\
\hline & Mid Essex & 375,200 & 0.86 & 0.85 & 0.86 & 0.83 & 0.83 & 0.79 & 0.70 & 0.89 & 714 & 4.4 \\
\hline & Norfolk & 762,000 & 0.94 & 0.92 & 0.89 & 0.85 & 0.82 & 0.79 & 0.73 & 0.85 & 761 & 3.5 \\
\hline & North East Essex & 311,700 & & 0.88 & 0.86 & 0.87 & 0.89 & 0.87 & 0.77 & 0.99 & 815 & 5.5 \\
\hline & Peterborough & 184,500 & 1.03 & 0.96 & 1.02 & 1.00 & 1.03 & 1.00 & 0.85 & 1.18 & 792 & 17.5 \\
\hline & South East Essex & 345,600 & 0.91 & 0.90 & 0.89 & 0.86 & 0.84 & 0.84 & 0.74 & 0.94 & 776 & 5.7 \\
\hline & South West Essex & 407,100 & 0.94 & 0.97 & 0.95 & 0.96 & 0.98 & 0.97 & 0.87 & 1.08 & 818 & 9.8 \\
\hline & Suffolk & 614,800 & 0.84 & 0.82 & 0.83 & 0.83 & 0.82 & 0.80 & 0.73 & 0.88 & 742 & 5.3 \\
\hline & West Essex & 289,600 & 0.75 & 0.69 & 0.71 & 0.75 & 0.74 & 0.82 & 0.72 & 0.94 & 732 & 8.1 \\
\hline \multirow[t]{4}{*}{ London } & Barking and Dagenham & 187,000 & 1.18 & 1.16 & 1.24 & 1.33 & 1.44 & 1.51 & 1.31 & 1.74 & 1027 & 41.7 \\
\hline & Barnet & 357,500 & 1.40 & 1.45 & 1.41 & 1.48 & 1.47 & 1.51 & 1.38 & 1.67 & 1172 & 35.9 \\
\hline & Bexley & 232,800 & 1.15 & 1.15 & 1.19 & 1.23 & 1.23 & 1.24 & 1.09 & 1.41 & 1044 & 18.1 \\
\hline & Brent Teaching & 312,200 & 1.79 & 2.01 & 2.10 & 2.20 & 2.20 & 2.23 & 2.04 & 2.43 & 1630 & 63.7 \\
\hline
\end{tabular}


Table 2.5. Continued

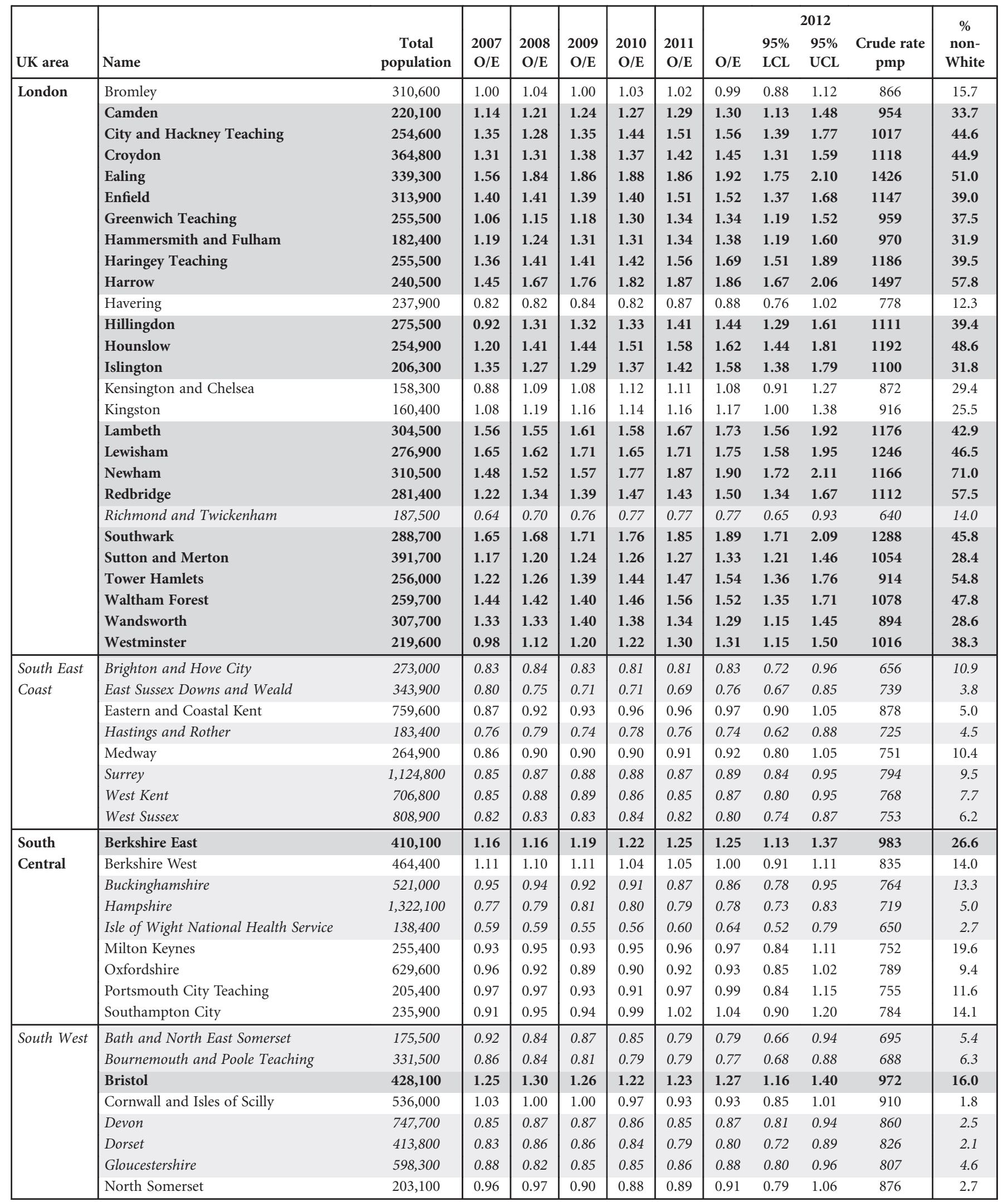


Table 2.5. Continued

\begin{tabular}{|c|c|c|c|c|c|c|c|c|c|c|c|c|}
\hline UK area & Name & $\begin{array}{c}\text { Total } \\
\text { population }\end{array}$ & $\begin{array}{l}2007 \\
\mathrm{O} / \mathrm{E}\end{array}$ & $\begin{array}{l}2008 \\
\mathrm{O} / \mathrm{E}\end{array}$ & $\begin{array}{c}2009 \\
\mathrm{O} / \mathrm{E}\end{array}$ & $\begin{array}{l}2010 \\
\mathrm{O} / \mathrm{E}\end{array}$ & $\begin{array}{c}2011 \\
\mathrm{O} / \mathrm{E}\end{array}$ & $\mathbf{O} / \mathbf{E}$ & $\begin{array}{l}95 \% \\
\text { LCL }\end{array}$ & $\begin{array}{c}2012 \\
95 \% \\
\text { UCL }\end{array}$ & $\begin{array}{c}\text { Crude rate } \\
\text { pmp }\end{array}$ & $\begin{array}{c}\% \\
\text { non- } \\
\text { White }\end{array}$ \\
\hline \multirow{3}{*}{ South West } & Somerset & 531,600 & 0.84 & 0.81 & 0.82 & 0.84 & 0.87 & 0.84 & 0.76 & 0.92 & 805 & 2.0 \\
\hline & South Gloucestershire & 263,400 & 1.01 & 1.00 & 0.94 & 1.00 & 0.97 & 0.95 & 0.83 & 1.08 & 839 & 5.0 \\
\hline & Swindon & 214,900 & 0.86 & 0.85 & 0.87 & 0.90 & 0.94 & 0.96 & 0.82 & 1.11 & 796 & 10.0 \\
\hline \multirow[t]{5}{*}{ Wales } & Betsi Cadwaladr University & 688,700 & 0.96 & 0.94 & 0.91 & 0.89 & 0.84 & 0.86 & 0.79 & 0.93 & 807 & 2.5 \\
\hline & Powys Teaching & 133,200 & 0.89 & 0.89 & 0.94 & 0.88 & 0.86 & 0.87 & 0.73 & 1.05 & 886 & 1.6 \\
\hline & Hywel Dda & 381,900 & 0.96 & 1.00 & 0.96 & 0.91 & 0.94 & 0.88 & 0.79 & 0.98 & 843 & 2.2 \\
\hline & Abertawe Bro Morgannwg University & 517,700 & 1.25 & 1.17 & 1.20 & 1.24 & 1.23 & 1.20 & 1.11 & 1.31 & 1084 & 3.9 \\
\hline & Cwm Taf & 293,500 & 1.51 & 1.43 & 1.39 & 1.31 & 1.35 & 1.27 & 1.14 & 1.41 & 1118 & 2.6 \\
\hline \multirow{11}{*}{ Scotland } & Dumfries and Galloway & 151,400 & 0.95 & 0.96 & 0.93 & 0.90 & 0.87 & 0.87 & 0.74 & 1.03 & 878 & 0.7 \\
\hline & Fife & 365,300 & 0.97 & 0.96 & 0.95 & 0.95 & 0.99 & 0.97 & 0.87 & 1.08 & 881 & 1.3 \\
\hline & Forth Valley & 298,100 & 0.96 & 0.93 & 0.92 & 0.93 & 0.89 & 0.87 & 0.76 & 0.99 & 778 & 1.1 \\
\hline & Grampian & 569,600 & 1.01 & 0.98 & 0.95 & 0.95 & 0.94 & 0.96 & 0.88 & 1.05 & 853 & 1.6 \\
\hline & Greater Glasgow \& Clyde & $1,214,600$ & 1.17 & 1.13 & 1.09 & 1.06 & 1.06 & 1.08 & 1.02 & 1.14 & 925 & 3.4 \\
\hline & Highland & 321,700 & 1.11 & 1.05 & 1.03 & 0.99 & 0.90 & 0.86 & 0.76 & 0.97 & 833 & 0.8 \\
\hline & Lanarkshire & 572,400 & 0.98 & 0.96 & 0.95 & 0.96 & 0.93 & 0.98 & 0.89 & 1.07 & 865 & 1.2 \\
\hline & Lothian & 836,600 & 0.96 & 0.93 & 0.90 & 0.86 & 0.82 & 0.82 & 0.76 & 0.89 & 694 & 2.8 \\
\hline & Orkney & 21,400 & 0.89 & 1.07 & 1.02 & 0.93 & 0.79 & 0.76 & 0.47 & 1.24 & 747 & 0.4 \\
\hline & Shetland & 23,200 & 0.71 & 0.50 & 0.54 & 0.57 & 0.49 & 0.48 & 0.26 & 0.89 & 430 & 1.1 \\
\hline & Tayside & 410,300 & 1.13 & 1.05 & 1.07 & 1.03 & 1.02 & 0.97 & 0.88 & 1.08 & 897 & 1.9 \\
\hline
\end{tabular}

(table 2.9). Furthermore, there existed a wide range between centres in the proportion of patients aged over 75 (9.2\% in Liverpool RI to $36.8 \%$ in Colchester).

Colchester had the highest median age (70.4 years), whilst Belfast the lowest (53.8 years) (table 2.8). This could reflect either variation in the demography of the catchment populations or follow-up of younger transplant patients (as above in the case of Belfast). The median age of the non-White dialysis population was lower than the overall dialysis population (60.9 vs. 66.1 years, data not shown). The differing age distributions of the transplant and dialysis populations are illustrated in figure 2.4, demonstrating that the age peak for prevalent dialysis patients is 24 years later than for prevalent transplant patients.
In the UK on 31st December 2012, 63.5\% of patients aged less than 65 years on RRT had a functioning transplant (table 2.15 ), compared with only $26.9 \%$ aged 65 years and over. There was a similar pattern in all four UK countries.

\section{Gender}

Standardising the age of the UK RRT prevalent patients, by using the age and gender distribution of the UK population by PCT/HB (from mid-2011 population estimates), allowed estimation of crude prevalence rates by age and gender (figure 2.5). This shows a progressive increase in prevalence rate with age, peaking at 2,138 pmp (a slight increase from 2,099 pmp in 2011) in the age group 7579 years before showing a reducing prevalence rate in 


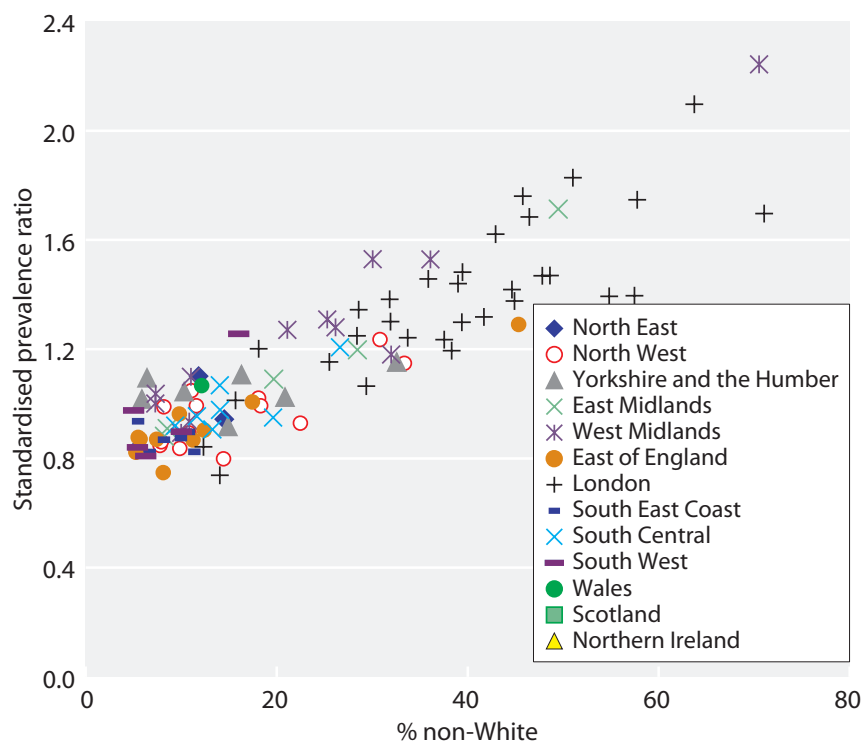

Fig. 2.3. Standardised prevalence ratios for all $\mathrm{PCT} / \mathrm{HB}$ areas by percentage non-White on 31/12/2012 (excluding areas with $<5 \%$ ethnic minorities)

age groups over 80 years. Crude prevalence rates in males exceeded those of females for all age groups, peaking in age group $80-84$ years at $2,973 \mathrm{pmp}$ and for females in age group 75-79 years at $1,528 \mathrm{pmp}$. Survival on RRT is described in chapter 8 .

\section{Ethnicity}

Fifty-nine of the 71 centres (83.1\%) provided ethnicity data that were at least $90 \%$ complete (table 2.10), an
Table 2.7. Median time on RRT of prevalent patients on $31 / 12 / 2012$

\begin{tabular}{lrc}
\hline Modality & $N$ & $\begin{array}{c}\text { Median time treated } \\
\text { (years) }\end{array}$ \\
\hline Haemodialysis & 23,034 & 3.4 \\
Peritoneal dialysis & 3,752 & 1.7 \\
Transplant & 26,365 & 10.2 \\
All RRT & $\mathbf{5 3 , 1 5 1}$ & $\mathbf{5 . 9}$ \\
\hline
\end{tabular}

All patients without a treatment modality were excluded

Median time on RRT was calculated from the most recent start date. For patients who recovered for $>90$ days and then subsequently restarted RRT the median time from the start of RRT was calculated from the most recent start date

Patients with an initial treatment modality of transferred in or transferred out were excluded from the calculation of median time on RRT since their treatment start date was not accurately known

improvement compared with 51 of $71(71.8 \%)$ in 2011 and 36 centres in 2006 . Ethnicity completeness for prevalent RRT patients improved in the UK from $88.6 \%$ in 2011 to $92.0 \%$ in 2012 , with $97.9 \%$ ethnicity completeness in England, 99.9\% completeness in Wales and 100\% in Northern Ireland. Completeness of ethnicity data was highest in prevalent transplant patients. This may relate to the fact that the intensive work-up for transplantation may increase the recording of data. Completeness of ethnicity data from Scotland was low at 33.6\%.

In 2012, 20.7\% of the prevalent UK RRT population (with ethnicity assigned) were from ethnic minorities (22.7\% in England). The proportion of the prevalent UK RRT population (with ethnicity assigned) from ethnic minorities in Wales, Scotland and Northern

Table 2.6. Standardised prevalence rate ratio of RRT for each Strategic Health Authority in England and for Wales, Scotland and Northern Ireland in 2012

\begin{tabular}{|c|c|c|c|c|c|}
\hline UK Area & Total population & $\mathrm{O} / \mathrm{E}$ & 95\% LCL & $95 \%$ UCL & Crude rate pmp \\
\hline North West & $7,089,100$ & 0.91 & 0.88 & 0.93 & 790.2 \\
\hline East Midlands & $4,506,800$ & 0.94 & 0.91 & 0.97 & 835.6 \\
\hline West Midlands & $5,608,700$ & 1.10 & 1.07 & 1.13 & 948.9 \\
\hline East of England & $5,862,400$ & 0.88 & 0.85 & 0.90 & 780.6 \\
\hline South Central & $4,182,300$ & 0.91 & 0.88 & 0.94 & 779.0 \\
\hline South West & $5,306,100$ & 0.89 & 0.87 & 0.92 & 829.4 \\
\hline Wales & $3,064,300$ & 1.02 & 0.99 & 1.06 & 925.2 \\
\hline Scotland & $5,299,900$ & 0.95 & 0.92 & 0.98 & 850.2 \\
\hline Northern Ireland & $1,814,300$ & 1.02 & 0.97 & 1.07 & 829.5 \\
\hline
\end{tabular}

$\mathrm{O} / \mathrm{E}$ - observed/expected prevalence rate ratio given the age/gender breakdown of each region

Bold - higher than expected prevalence rate ratio 
Table 2.8. Median age of prevalent RRT patients by treatment modality in renal centres on 31/12/2012

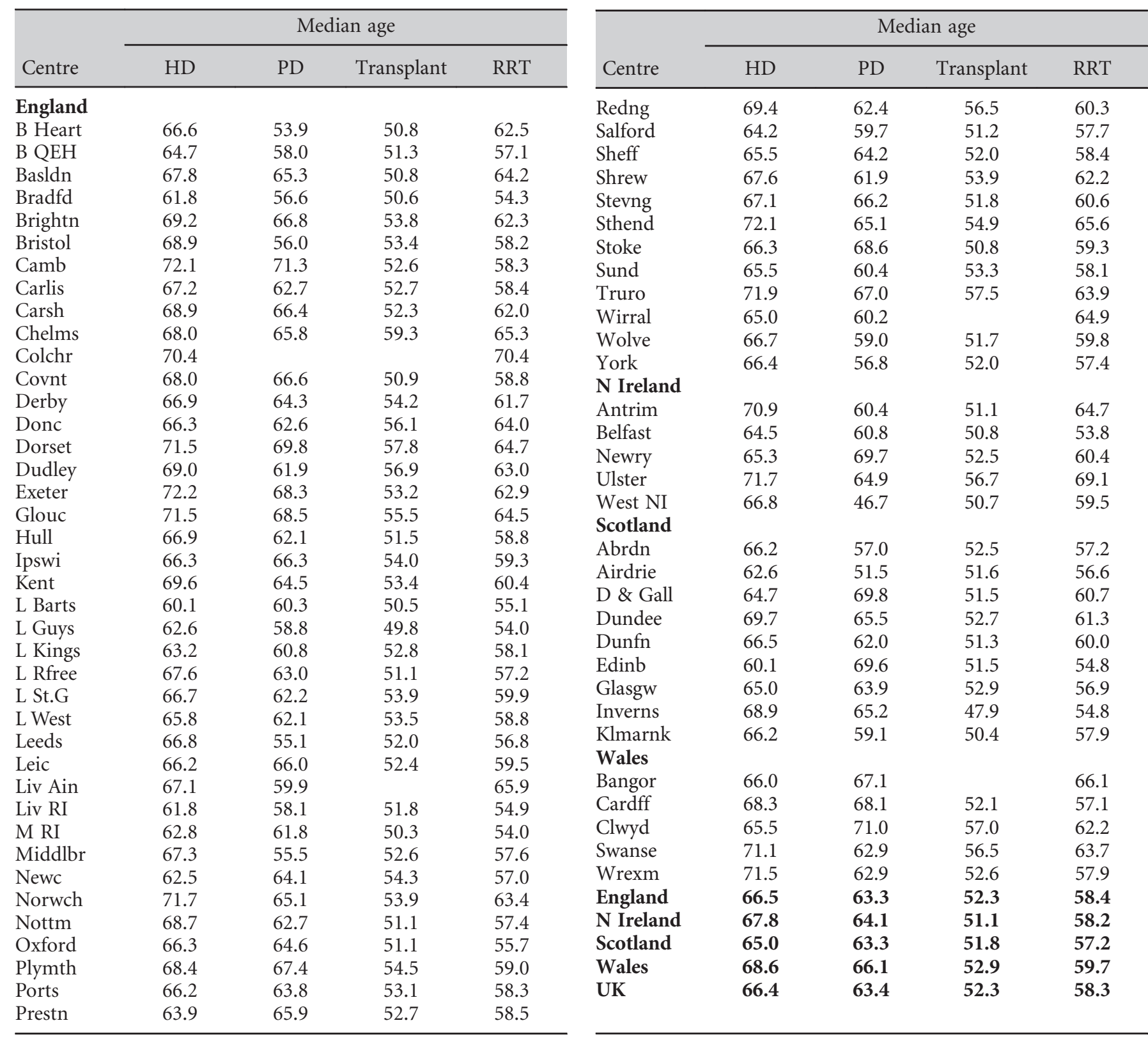

Blank cells indicate no patients on that treatment modality attending that centre when data were collected

Ireland were very small, although it should be noted that there was a high level of missing ethnicity data in Scotland. The ONS estimates that approximately 14\% of the UK general population are designated as belonging to an ethnic minority [1]. The relative proportion of patients reported to the UKRR as receiving RRT and belonging to an ethnic minority has increased from $14.9 \%$ in 2007 which may be due to improvements in coding and reporting of ethnicity data as well as an increasing incidence of ERF and increased referral rates in these populations.

Amongst the centres with more than 50\% returns there was wide variation in the proportion of patients from ethnic minorities, ranging from $0.5 \%$ in two centres (Truro and Newry) to over $50 \%$ in 3 centres: London Barts (60.2\%), London West (55.5\%) and London Royal 
Table 2.9. Percentage of prevalent RRT patients in each age group by centre on $31 / 12 / 2012$

\begin{tabular}{|c|c|c|c|c|c|}
\hline \multirow[b]{2}{*}{ Centre } & \multirow[b]{2}{*}{$N$} & \multicolumn{4}{|c|}{ Percentage of patients } \\
\hline & & $18-39$ years & 40-64 years & $65-74$ years & $75+$ years \\
\hline \multicolumn{6}{|l|}{ England } \\
\hline B Heart & 670 & 14.0 & 42.8 & 22.8 & 20.3 \\
\hline B QEH & 1,971 & 14.9 & 52.0 & 17.7 & 15.4 \\
\hline Basldn & 264 & 12.5 & 39.4 & 22.0 & 26.1 \\
\hline Bristol & 1,337 & 16.1 & 47.9 & 20.0 & 15.9 \\
\hline Camb & 1,113 & 14.0 & 50.7 & 20.0 & 15.3 \\
\hline Carlis & 216 & 13.9 & 53.2 & 19.9 & 13.0 \\
\hline Carsh & 1,475 & 10.6 & 45.9 & 22.6 & 20.8 \\
\hline Chelms & 224 & 7.6 & 41.1 & 25.4 & 25.9 \\
\hline Dorset & 610 & 9.8 & 41.1 & 28.7 & 20.3 \\
\hline Dudley & 316 & 7.3 & 48.7 & 20.9 & 23.1 \\
\hline Exeter & 846 & 10.0 & 44.4 & 23.6 & 21.9 \\
\hline Glouc & 417 & 10.1 & 42.2 & 23.0 & 24.7 \\
\hline Hull & 789 & 13.6 & 50.6 & 20.2 & 15.7 \\
\hline Ipswi & 339 & 10.3 & 54.9 & 21.8 & 13.0 \\
\hline Kent & 922 & 12.9 & 46.3 & 23.8 & 17.0 \\
\hline L Barts & 1,955 & 17.3 & 55.1 & 16.6 & 11.0 \\
\hline L Guys & 1,745 & 19.7 & 53.6 & 15.6 & 11.0 \\
\hline L Kings & 918 & 12.3 & 51.7 & 20.4 & 15.6 \\
\hline L Rfree & 1,865 & 17.8 & 48.3 & 18.4 & 15.5 \\
\hline Newc & 946 & 14.4 & 53.7 & 21.5 & 10.5 \\
\hline Norwch & 612 & 11.3 & 41.8 & 22.5 & 24.3 \\
\hline Nottm & 1,006 & 16.3 & 48.8 & 19.1 & 15.8 \\
\hline Oxford & 1,535 & 16.3 & 53.0 & 17.6 & 13.1 \\
\hline Plymth & 459 & 13.5 & 49.5 & 24.4 & 12.6 \\
\hline Ports & 1,447 & 14.0 & 50.9 & 20.6 & 14.5 \\
\hline Prestn & 1,081 & 12.4 & 53.4 & 20.5 & 13.7 \\
\hline Redng & 671 & 10.1 & 49.2 & 22.5 & 18.2 \\
\hline Salford & 882 & 13.8 & 52.3 & 20.6 & 13.3 \\
\hline Sheff & 1,307 & 13.8 & 51.6 & 19.2 & 15.3 \\
\hline Shrew & 354 & 12.1 & 44.4 & 21.2 & 22.3 \\
\hline Stevng & 665 & 12.2 & 46.6 & 20.5 & 20.8 \\
\hline Sthend & 213 & 13.6 & 34.7 & 24.4 & 27.2 \\
\hline Stoke & 695 & 14.8 & 46.5 & 20.0 & 18.7 \\
\hline Sund & 421 & 12.8 & 52.7 & 21.6 & 12.8 \\
\hline Truro & 377 & 12.2 & 40.3 & 24.4 & 23.1 \\
\hline Wirral & 234 & 7.7 & 43.2 & 21.8 & 27.4 \\
\hline Wolve & 528 & 10.8 & 49.8 & 20.8 & 18.6 \\
\hline York & 396 & 19.2 & 46.2 & 21.7 & 12.9 \\
\hline
\end{tabular}


Table 2.9. Continued

\begin{tabular}{|c|c|c|c|c|c|}
\hline \multirow[b]{2}{*}{ Centre } & \multirow[b]{2}{*}{$N$} & \multicolumn{4}{|c|}{ Percentage of patients } \\
\hline & & $18-39$ years & 40-64 years & 65-74 years & $75+$ years \\
\hline Antrim & 225 & 10.2 & 40.4 & 25.3 & 24.0 \\
\hline Belfast & 701 & 17.4 & 54.6 & 17.1 & 10.8 \\
\hline Newry & 188 & 14.9 & 47.9 & 22.9 & 14.4 \\
\hline \multicolumn{6}{|l|}{ Scotland } \\
\hline Abrdn & 504 & 19.0 & 50.2 & 17.5 & 13.3 \\
\hline Airdrie & 388 & 15.5 & 52.1 & 18.0 & 14.4 \\
\hline D \& Gall & 128 & 12.5 & 47.7 & 22.7 & 17.2 \\
\hline Dundee & 403 & 12.2 & 46.2 & 22.1 & 19.6 \\
\hline Dunfn & 278 & 13.3 & 46.8 & 24.1 & 15.8 \\
\hline \multicolumn{6}{|l|}{ Wales } \\
\hline Bangor & 105 & 8.6 & 37.1 & 30.5 & 23.8 \\
\hline Cardff & 1,548 & 15.1 & 51.6 & 19.6 & 13.7 \\
\hline Clwyd & 172 & 12.2 & 45.3 & 26.7 & 15.7 \\
\hline Swanse & 662 & 10.7 & 42.6 & 24.0 & 22.7 \\
\hline Wrexm & 249 & 16.5 & 44.6 & 17.7 & 21.3 \\
\hline England & 46,076 & 14.2 & 49.8 & 20.3 & 15.7 \\
\hline N Ireland & 1,520 & 15.2 & 48.0 & 20.7 & 16.1 \\
\hline Scotland & 4,492 & 14.4 & 53.0 & 19.1 & 13.4 \\
\hline Wales & 2,736 & 13.7 & 47.8 & 21.4 & 17.1 \\
\hline UK & 54,824 & 14.2 & 50.0 & 20.2 & 15.6 \\
\hline$(\min : \max )$ & & $(5.1: 20.7)$ & $(27.4: 57.7)$ & $(13.8: 30.8)$ & $(9.2: 36.8)$ \\
\hline
\end{tabular}

Free (50.9\%). Three additional centres had over $40 \%$ of prevalent patients from ethnic minorities: Bradford (42.3\%), London Kings (48.5\%) and London St Georges (44.6\%).

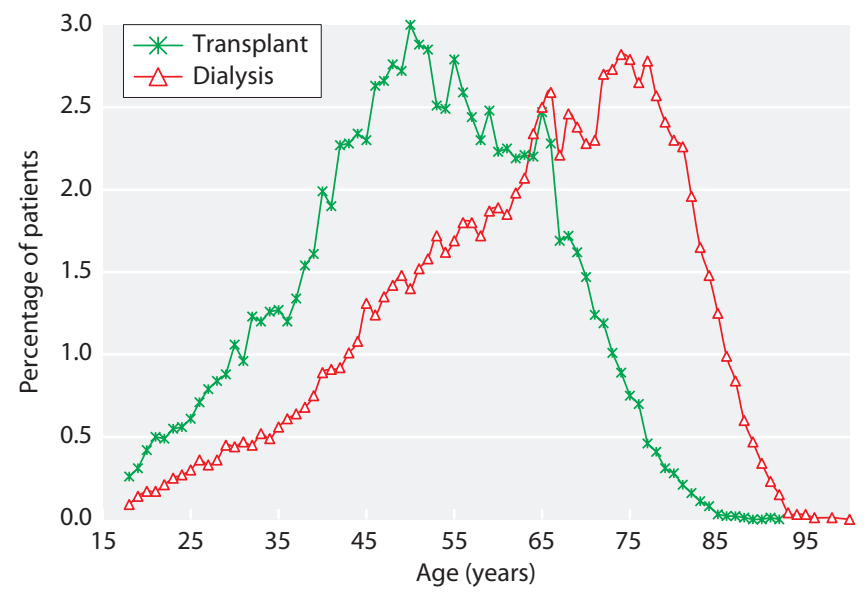

Fig. 2.4. Age profile of prevalent RRT patients by modality on $31 / 12 / 2012$

\section{Primary renal diagnosis}

Data for primary renal diagnosis (PRD) were not complete for $3.6 \%$ of patients (table 2.11) and there remained a marked inter-centre difference in completeness of data

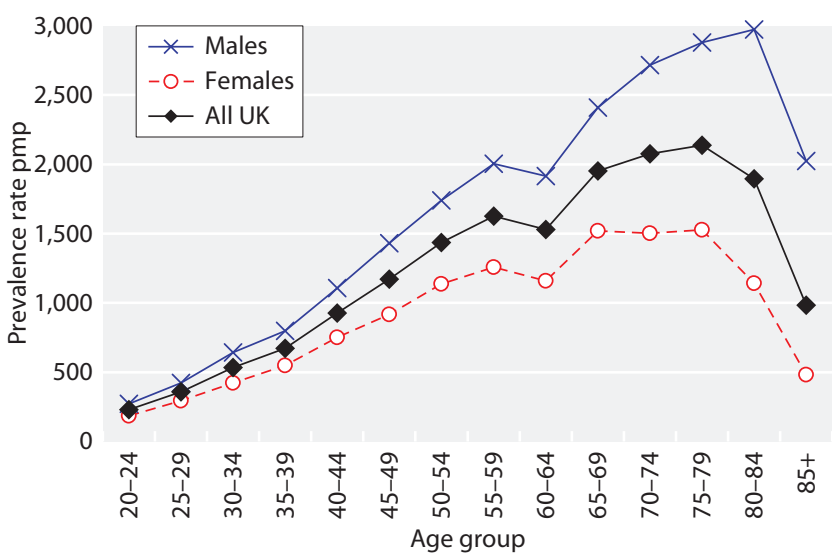

Fig. 2.5. Prevalence rate of RRT patients per million population by age and gender on $31 / 12 / 2012$ 
Table 2.10. Ethnicity of prevalent RRT patients by centre on $31 / 12 / 2012$

\begin{tabular}{|c|c|c|c|c|c|c|c|}
\hline \multirow[b]{2}{*}{ Centre } & \multirow{2}{*}{$\begin{array}{l}\text { Data not } \\
\text { available }\end{array}$} & \multirow{2}{*}{$\begin{array}{c}N \\
\text { with data }\end{array}$} & \multicolumn{5}{|c|}{ Percentage in each ethnic group } \\
\hline & & & White & Black & S Asian & Chinese & Other \\
\hline B Heart & 0.0 & 670 & 61.9 & 7.2 & 29.6 & 0.6 & 0.7 \\
\hline B QEH & 0.0 & 1,971 & 64.3 & 9.0 & 23.4 & 0.9 & 2.4 \\
\hline Basldn & 0.0 & 264 & 85.2 & 8.3 & 4.2 & 0.8 & 1.5 \\
\hline Bristol & 0.4 & 1,331 & 89.9 & 5.0 & 3.6 & 0.4 & 1.1 \\
\hline Camb & 1.2 & 1,100 & 93.1 & 1.9 & 4.0 & 0.2 & 0.8 \\
\hline Carlis & 0.0 & 216 & 99.1 & 0.0 & 0.9 & 0.0 & 0.0 \\
\hline Carsh & 6.8 & 1,374 & 72.9 & 9.6 & 12.7 & 1.5 & 3.3 \\
\hline Chelms & 5.4 & 212 & 92.5 & 2.8 & 1.9 & 0.9 & 1.9 \\
\hline Dorset & 0.0 & 610 & 97.5 & 0.2 & 0.7 & 0.5 & 1.1 \\
\hline Dudley & 0.0 & 316 & 86.4 & 2.8 & 8.9 & 0.6 & 1.3 \\
\hline Exeter & 0.2 & 844 & 98.3 & 0.6 & 0.4 & 0.2 & 0.5 \\
\hline Glouc & 0.0 & 417 & 94.2 & 1.7 & 2.9 & 0.0 & 1.2 \\
\hline Hull & 37.3 & 495 & 97.2 & 0.6 & 1.6 & 0.2 & 0.4 \\
\hline Ipswi & 1.2 & 335 & 94.0 & 3.0 & 2.7 & 0.3 & 0.0 \\
\hline Kent & 0.7 & 916 & 94.9 & 0.7 & 3.2 & 0.1 & 1.2 \\
\hline L Barts & 0.0 & 1,955 & 39.8 & 32.4 & 25.8 & 1.5 & 0.4 \\
\hline L Guys & 0.9 & 1,730 & 67.0 & 22.0 & 6.4 & 1.2 & 3.4 \\
\hline L Kings & 1.9 & 901 & 51.5 & 34.4 & 11.0 & 1.7 & 1.4 \\
\hline L Rfree & 3.1 & 1,807 & 49.1 & 21.7 & 19.0 & 1.6 & 8.5 \\
\hline Newc & 0.1 & 945 & 93.4 & 0.7 & 4.2 & 0.7 & 0.8 \\
\hline Norwch & 0.5 & 609 & 96.1 & 0.5 & 1.0 & 2.1 & 0.3 \\
\hline Nottm & 0.0 & 1,006 & 87.0 & 5.1 & 6.5 & 0.0 & 1.5 \\
\hline Oxford & 2.0 & 1,505 & 83.7 & 3.7 & 9.3 & 0.6 & 2.7 \\
\hline Plymth & 0.0 & 459 & 97.4 & 0.7 & 0.4 & 0.7 & 0.9 \\
\hline Ports & 1.1 & 1,431 & 94.3 & 0.9 & 3.1 & 0.0 & 1.7 \\
\hline Prestn & 0.0 & 1,081 & 85.8 & 0.8 & 12.8 & 0.0 & 0.6 \\
\hline Redng & 4.9 & 638 & 71.2 & 6.7 & 20.4 & 0.2 & 1.6 \\
\hline Salford & 1.6 & 868 & 82.1 & 1.7 & 14.2 & 0.5 & 1.5 \\
\hline Sheff & 0.5 & 1,301 & 91.8 & 2.2 & 3.8 & 0.7 & 1.5 \\
\hline Shrew & 0.6 & 352 & 96.0 & 1.4 & 2.3 & 0.0 & 0.3 \\
\hline Stevng & 0.3 & 663 & 69.4 & 9.5 & 17.6 & 0.6 & 2.9 \\
\hline Sthend & 0.0 & 213 & 84.5 & 2.3 & 4.2 & 2.3 & 6.6 \\
\hline Stoke & 15.5 & 587 & 93.4 & 0.3 & 4.3 & 0.3 & 1.7 \\
\hline Sund & 0.2 & 420 & 96.9 & 0.7 & 2.1 & 0.2 & 0.0 \\
\hline Truro & 0.0 & 377 & 99.5 & 0.0 & 0.3 & 0.0 & 0.3 \\
\hline Wirral & 1.3 & 231 & 95.2 & 0.4 & 1.7 & 1.3 & 1.3 \\
\hline Wolve & 0.0 & 528 & 71.4 & 9.1 & 19.3 & 0.2 & 0.0 \\
\hline York & 3.3 & 383 & 97.4 & 0.5 & 1.6 & 0.0 & 0.5 \\
\hline
\end{tabular}


Table 2.10. Continued

\begin{tabular}{|c|c|c|c|c|c|c|c|}
\hline \multirow[b]{2}{*}{ Centre } & \multirow{2}{*}{$\begin{array}{l}\text { Data not } \\
\text { available }\end{array}$} & \multirow{2}{*}{$\begin{array}{c}N \\
\text { with data }\end{array}$} & \multicolumn{5}{|c|}{ Percentage in each ethnic group } \\
\hline & & & White & Black & S Asian & Chinese & Other \\
\hline \multicolumn{8}{|l|}{$\mathrm{N}$ Ireland } \\
\hline Antrim & 0.0 & 225 & 99.1 & 0.0 & 0.9 & 0.0 & 0.0 \\
\hline Belfast & 0.0 & 701 & 98.4 & 0.1 & 1.0 & 0.3 & 0.1 \\
\hline Newry & 0.0 & 188 & 99.5 & 0.0 & 0.0 & 0.5 & 0.0 \\
\hline Ulster & 0.0 & 148 & 97.3 & 0.0 & 2.0 & 0.7 & 0.0 \\
\hline West NI & 0.0 & 258 & 98.4 & 0.4 & 0.8 & 0.4 & 0.0 \\
\hline \multicolumn{8}{|l|}{ Scotland } \\
\hline Abrdn & 60.7 & 198 & & & & & \\
\hline Airdrie & 66.2 & 131 & & & & & \\
\hline D \& Gall & 88.3 & 15 & & & & & \\
\hline Dundee & 55.8 & 178 & & & & & \\
\hline Dunfn & 82.4 & 49 & & & & & \\
\hline Edinb & 93.1 & 50 & & & & & \\
\hline Glasgw & 92.5 & 116 & & & & & \\
\hline Inverns & 14.7 & 186 & 98.9 & 0.0 & 1.1 & 0.0 & 0.0 \\
\hline Klmarnk & 55.0 & 136 & & & & & \\
\hline \multicolumn{8}{|l|}{ Wales } \\
\hline Bangor & 0.0 & 105 & 96.2 & 1.0 & 1.0 & 0.0 & 1.9 \\
\hline Cardff & 0.2 & 1,545 & 94.2 & 0.9 & 4.0 & 0.5 & 0.4 \\
\hline Clwyd & 0.6 & 171 & 98.8 & 0.0 & 0.6 & 0.6 & 0.0 \\
\hline Swanse & 0.0 & 662 & 97.9 & 0.3 & 1.5 & 0.0 & 0.3 \\
\hline Wrexm & 0.0 & 249 & 99.2 & 0.4 & 0.4 & 0.0 & 0.0 \\
\hline England & 2.1 & 45,104 & 77.3 & 8.1 & 12.1 & 0.7 & 1.9 \\
\hline $\mathrm{N}$ Ireland & 0.0 & 1,520 & 98.6 & 0.1 & 0.9 & 0.3 & 0.1 \\
\hline Scotland & 76.4 & 1,059 & & & & & \\
\hline Wales & 0.1 & 2,732 & 95.9 & 0.7 & 2.7 & 0.3 & 0.4 \\
\hline UK & 8.0 & 50,415 & 79.3 & 7.3 & 11.0 & 0.7 & 1.7 \\
\hline
\end{tabular}

Percentage breakdown is not shown for centres with less than $50 \%$ data completeness, but these centres are included in national averages Blank cells - less than $50 \%$ data completeness

Appendix $\mathrm{H}$ ethnicity coding

returns. Only one centre had $40 \%$ primary renal diagnosis data coded as uncertain and has been excluded from the between centre analysis and other analyses where PRD is included in the case-mix adjustment (Colchester,
48\% uncertain PRD); the UK and national totals have been appropriately adjusted. The range for the remaining 70 centres was between $5.0 \%$ and $34.5 \%$, and has shown improvement over time. Completeness of PRD data has

Table 2.11. Primary renal diagnosis in prevalent RRT patients by age and gender on $31 / 12 / 2012$

\begin{tabular}{|c|c|c|c|c|c|c|c|c|}
\hline \multirow[b]{2}{*}{ Primary diagnosis* } & \multirow[b]{2}{*}{$N$} & \multirow{2}{*}{$\begin{array}{c}\% \text { all } \\
\text { patients }\end{array}$} & \multirow{2}{*}{$\begin{array}{l}\text { Inter- } \\
\text { centre } \\
\text { range \% }\end{array}$} & \multicolumn{2}{|c|}{ Age $<65$} & \multicolumn{2}{|c|}{ Age 65} & \multirow{2}{*}{$\begin{array}{l}\mathrm{M}: \mathrm{F} \\
\text { ratio }\end{array}$} \\
\hline & & & & $N$ & $\%$ & $N$ & $\%$ & \\
\hline Aetiology uncertain & 9,154 & 16.7 & $5.0-34.5$ & 5,092 & 14.5 & 4,062 & 20.7 & 1.6 \\
\hline Glomerulonephritis & 10,289 & 18.8 & $8.5-28.6$ & 7,523 & 21.4 & 2,766 & 14.1 & 2.1 \\
\hline Pyelonephritis & 6,008 & 11.0 & $3.9-18.5$ & 4,473 & 12.7 & 1,535 & 7.8 & 1.1 \\
\hline Diabetes & 8,456 & 15.5 & $9.6-24.9$ & 5,064 & 14.4 & 3,392 & 17.3 & 1.6 \\
\hline Polycystic kidney & 5,286 & 9.7 & $4.1-16.7$ & 3,510 & 10.0 & 1,776 & 9.1 & 1.1 \\
\hline Hypertension & 3,249 & 5.9 & $1.5-15.4$ & 1,773 & 5.0 & 1,476 & 7.5 & 2.4 \\
\hline Renal vascular disease & 1,743 & 3.2 & $0.6-9.1$ & 354 & 1.0 & 1,389 & 7.1 & 2.0 \\
\hline Other & 8,568 & 15.7 & $9.5-25.3$ & 6,071 & 17.3 & 2,497 & 12.8 & 1.3 \\
\hline Not sent & 1,954 & 3.6 & $0.2-37.5$ & 1,266 & 3.6 & 688 & 3.5 & 1.6 \\
\hline
\end{tabular}

*Appendix H: ERA-EDTA coding

Excluded centre: $40 \%$ primary renal diagnosis aetiology uncertain (Colchr) 
also continued to improve and no centres had $>50 \%$ missing data in 2012.

Glomerulonephritis (GN) remained the most common primary renal diagnosis in the 2012 prevalent cohort at $18.8 \%$ (table 2.11). Diabetes accounted for $15.5 \%$ of renal disease in prevalent patients on RRT, although it was more common in the 65 year age group compared to the younger group (17.3\% vs. $14.4 \%)$. This contrasted with incident patients where diabetes was the predominant diagnostic code in $25.6 \%$ of new RRT patients. Younger patients (age $<65$ years) are more likely to have GN or pyelonephritis and less likely to have renal vascular disease or hypertension as the cause of their renal failure.

As described before, the male:female ratio was greater than unity for all primary renal diagnoses (table 2.11).

In individuals aged less than 65 years, renal transplantation to dialysis ratio was greater than 1 in all PRD groups except diabetes and renovascular disease. In those aged $>65$ years, dialysis was more prevalent than renal transplantation in all PRD groups except polycystic kidney disease (PKD) (table 2.12).

\section{Diabetes}

Diabetes included all prevalent patients with type 1 or type 2 diabetes as the primary renal diagnosis (ERAEDTA coding) and did not include patients with diabetes as a comorbidity. This analysis did not differentiate between type 1 and type 2 diabetes as this distinction was not made in the data submitted by most centres.

The number of prevalent patients with diabetes as a primary renal diagnosis increased $8.4 \%$ to 8,456 in

Table 2.12. Transplant: dialysis ratios by age and primary renal disease in the prevalent RRT population on 31/12/2012

\begin{tabular}{lcc}
\hline & \multicolumn{2}{c}{ Transplant: dialysis ratio } \\
\cline { 2 - 3 } Primary diagnosis & $<65$ & 65 \\
\hline Aetiology uncertain & 1.8 & 0.3 \\
Glomerulonephritis & 2.2 & 0.7 \\
Pyelonephritis & 2.5 & 0.4 \\
Diabetes & 0.8 & 0.1 \\
Polycystic kidney & 2.3 & 1.4 \\
Hypertension & 1.1 & 0.3 \\
Renal vascular disease & 0.9 & 0.1 \\
Other & 1.9 & 0.3 \\
Not sent & 2.1 & 0.3 \\
\hline
\end{tabular}

*Appendix H ERA-EDTA coding

Excluded centre: $40 \%$ primary renal diagnosis aetiology uncertain (Colchr)
2012 , from 7,798 in 2011 , representing $15.5 \%$ of all prevalent patients (compared with 13.5\% in 2006) (table 2.13). The median age at start of RRT for patients with diabetes (56 years) was nine years higher compared with patients without diabetes (47 years), although the median age at the end of 2012 for prevalent diabetic patients was only three years higher than for individuals without diabetes. This reflects reduced survival for patients with diabetes compared with patients without diabetes on RRT. Median time on RRT for patients with diabetes was less when compared with patients without diabetes (3.5 years vs. 6.7 years) and this difference in survival has not changed over the last five years. Patients with diabetes starting RRT in Scotland were three years younger and in Northern Ireland three years older compared with the UK average age of patients with diabetes starting RRT (data not shown).

Sixty percent of patients with diabetes as primary renal diagnosis were undergoing HD. In patients with a different primary renal diagnosis $39 \%$ were undergoing $\mathrm{HD}$ (table 2.13). The percentage of patients with a functioning transplant was much lower in prevalent patients with diabetes than in prevalent patients without diabetes ( $32 \%$ vs. $54 \%$ ). However, the proportion of patients with diabetes as PRD with a functioning transplant has

Table 2.13. Age relationships in patients with diabetes and patients without diabetes and modality in prevalent RRT patients on $31 / 12 / 2012$

\begin{tabular}{|c|c|c|}
\hline & $\begin{array}{c}\text { Patients with } \\
\text { diabetes }^{\mathrm{a}}\end{array}$ & $\begin{array}{l}\text { Patients without } \\
\text { diabetes }^{\mathrm{b}}\end{array}$ \\
\hline$N$ & 8,456 & 44,297 \\
\hline $\mathrm{M}: \mathrm{F}$ ratio & 1.59 & 1.54 \\
\hline Median age on $31 / 12 / 12$ & 61 & 58 \\
\hline Median age at start of $\mathrm{RRT}^{\mathrm{cd}}$ & 56 & 47 \\
\hline Median years on RRT $^{\mathrm{d}}$ & 3.5 & 6.7 \\
\hline$\% \mathrm{HD}^{\mathrm{e}}$ & 60 & 39 \\
\hline$\% \mathrm{PD}^{\mathrm{e}}$ & 9 & 6 \\
\hline$\%$ transplant $^{\mathrm{e}}$ & 32 & 54 \\
\hline
\end{tabular}

Excluded centre: $40 \%$ primary renal diagnosis aetiology uncertain (Colchr)

${ }^{a}$ Patients with diabetes: patients with a primary renal disease code of diabetes

${ }^{b}$ Patients without diabetes: all patients excluding patients with diabetes and patients with a missing primary renal disease code

${ }^{\mathrm{c}}$ Median age at start of RRT was calculated from the most recent RRT start date

${ }^{\mathrm{d}}$ Patients with an initial treatment modality of transferred in or transferred out were excluded from the calculation of median age at start of RRT and median years on RRT, since their treatment start date was not accurately known

${ }^{\mathrm{e}}$ Patients without a treatment modality code were excluded from calculating the $\%$ per treatment modality 
Table 2.14. Treatment modalities by age and diabetes status on $31 / 12 / 2012$

\begin{tabular}{|c|c|c|c|c|}
\hline & \multicolumn{2}{|c|}{$<65$ years } & \multicolumn{2}{|c|}{65 years } \\
\hline & Diabetes $^{\mathrm{a}}$ & $\begin{array}{l}\text { All other } \\
\text { causes }\end{array}$ & Diabetes $^{a}$ & $\begin{array}{l}\text { All other } \\
\text { causes }\end{array}$ \\
\hline$N$ & 5,064 & 28,796 & 3,392 & 15,501 \\
\hline$\% \mathrm{HD}$ & 46.8 & 28.0 & 78.9 & 60.7 \\
\hline$\% \mathrm{PD}$ & 8.2 & 5.3 & 9.7 & 8.6 \\
\hline$\%$ transplant & 45.0 & 66.7 & 11.4 & 30.6 \\
\hline
\end{tabular}

Excludes all patients without a treatment modality code Excluded centre with 40\% PRD aetiology uncertain (Colchr)

${ }^{a}$ Patients with diabetes are patients with a primary renal disease code of diabetes

${ }^{b}$ Patients without diabetes are calculated as all patients excluding patients with diabetes and patients with a missing primary renal disease code

increased since 2004 when only $26 \%$ of patients with diabetes had a functioning transplant. For older patients with diabetes (age 65 years), 11.4\% had a functioning transplant compared with $30.6 \%$ of their peers without diabetes (table 2.14). In Northern Ireland, $23.6 \%$ of prevalent patients with diabetes had a functioning transplant compared with the UK average of $31.5 \%$ although on average the Northern Ireland patients with diabetes were older by three years (data not shown). A higher proportion of prevalent patients without diabetes (18.7\%) were on home dialysis therapies (home HD and PD) compared with prevalent patients with diabetes $(14.8 \%)$.

\section{Modalities of treatment}

Transplantation was the most common treatment modality (50.4\%) for prevalent RRT patients in 2012, followed closely by centre-based HD (40.7\%) in either hospital centre (19.4\%) or satellite unit (21.3\%) (figure 2.6). Satellite based haemodialysis was more prevalent than hospital centre haemodialysis for the first time in 2012 . Home therapies made up the remaining $8.9 \%$ of treatment therapies, largely PD in its different formats (6.9\%) which was similar to 2011 . The proportion on continuous ambulatory peritoneal dialysis (CAPD) and automated PD (APD) was $3.4 \%$ and $3.5 \%$ respectively, although the proportion on APD may be an underestimate due to centre level coding issues which mean the UKRR cannot always distinguish between these therapies. The term CAPD has been used for patients receiving non-disconnect as well as disconnect CAPD systems, because the proportion of patients using nondisconnect systems was very small.

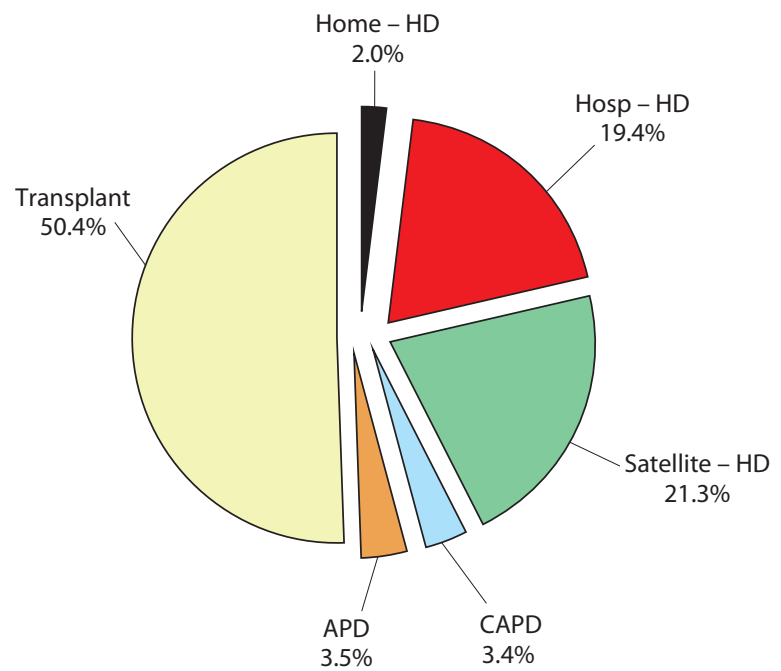

Fig. 2.6. Treatment modality in prevalent RRT patients on 31/12/ 2012

As mentioned earlier, treatment modality was related to patient age. Younger patients (age $<65$ years), were more likely to have a functioning transplant (63.5\%) when compared with patients aged over 65 years (26.9\%) (table 2.15). HD was the principal modality in the older patients (64.1\%). However, in the elderly, interpreting the proportion of patients on renal replacement therapy who are transplanted is not straight forward as this depends on approaches to dialysis and conservative care in this age group.

Figure 2.7 shows the association between age and RRT modality. Beyond 54 years of age, transplant prevalence declined, whilst HD prevalence increased. The proportion of each age group treated by PD remained more stable across the age spectrum.

The proportion of prevalent dialysis patients receiving HD, ranged from $69.3 \%$ in Carlisle to $100 \%$ in Colchester (table 2.16).

Overall, the proportion of dialysis patients treated in a satellite haemodialysis unit has increased to $42.9 \%$ this year compared to $41.5 \%$ in 2011 , and $39.9 \%$ in 2010 . Although there are satellite units in Scotland, the data provided for 2012 did not distinguish between main centre and satellite unit haemodialysis. In 2012, the number of centres that had more than $50 \%$ of their haemodialysis activity taking place in satellite units was 28, an increase from 2011 (table 2.16 and figure 2.8). There was also wide variation between centres in the proportion of dialysis patients on APD treatment, ranging from $0 \%$ to $19.4 \%$ (table 2.16). Twelve of the 70 centres with a PD programme did not report having any patients 
Table 2.15. Percentage of prevalent RRT patients by dialysis and transplant modality by UK country on $31 / 12 / 2012$

\begin{tabular}{|c|c|c|c|c|c|c|c|c|}
\hline \multirow[b]{2}{*}{ UK country } & \multicolumn{4}{|c|}{$<65$ years } & \multicolumn{4}{|c|}{65 years } \\
\hline & $N$ & $\% \mathrm{HD}$ & $\% \mathrm{PD}$ & $\%$ transplant & $N$ & $\% \mathrm{HD}$ & $\% \mathrm{PD}$ & $\%$ transplant \\
\hline N Ireland & 961 & 30.6 & 4.5 & 64.9 & 559 & 71.6 & 7.3 & 21.1 \\
\hline Scotland & 3,028 & 31.6 & 4.2 & 64.3 & 1,464 & 65.6 & 7.5 & 26.9 \\
\hline Wales & 1,684 & 26.5 & 5.6 & 67.9 & 1,052 & 60.2 & 10.1 & 29.8 \\
\hline
\end{tabular}

All patients without a treatment modality code were excluded

on APD, whilst in the Northern Ireland centres almost all PD patients were on this form of the modality.

\section{Home haemodialysis}

The use of home HD as a RRT peaked in 1982 when almost 2,200 patients were estimated to be on this modality, representing $61 \%$ of HD patients reported to the ERA-EDTA Registry at that time. The fall in the use of this modality to just 445 patients $(2.4 \%$ of $\mathrm{HD}$ patients) in 2006 was probably due to an increase in availability and uptake of renal transplantation, and also the similar expansion of hospital HD provision with the introduction of satellite units. In the last seven years there has been renewed interest in home HD and a target of $15 \%$ of HD patients on this modality has been suggested [6]. Equipment changes and patient choice has helped drive this change. Since 2006 there has been a gradual increase in the proportion of prevalent patients receiving haemodialysis in their own homes so that in 2012 it reached $4.6 \%$ of HD patients $(n=1,080$, figure 2.2). These numbers may be an underestimate as some centres have been unable to submit data for patients coded as home HD and work is ongoing to address this.
In 2012, the percentage of dialysis patients receiving home HD varied from $0 \%$ in eight centres, to greater than $5 \%$ in 23 centres (table 2.16). In the UK, the overall percentage of dialysis patients receiving home haemodialysis has increased from $3.4 \%$ in 2011 to $4.0 \%$ in 2012.

The proportion of dialysis patients receiving home haemodialysis was greatest in Wales at 5.9\%, compared with $4.9 \%$ in Northern Ireland, 3.9\% in England and $2.9 \%$ in Scotland (figure 2.8, table 2.16). The proportion on home haemodialysis has increased in each of the four countries since 2011. Forty-seven renal centres across the UK had an increase in the proportion of individuals on home haemodialysis compared with 2011. In 2007, for comparison, the proportion of patients receiving home haemodialysis was $2 \%$ in each of the four UK countries.

\section{Change in modality}

The relative proportion of RRT modalities in prevalent patients has changed dramatically over the past decade. The main features are depicted in figure 2.9, which describes a decline in the proportion of patients treated by PD after 2000 . This may however have started to

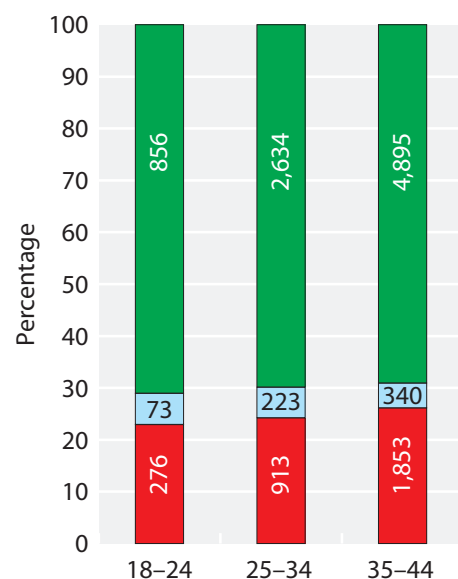

$18-24$
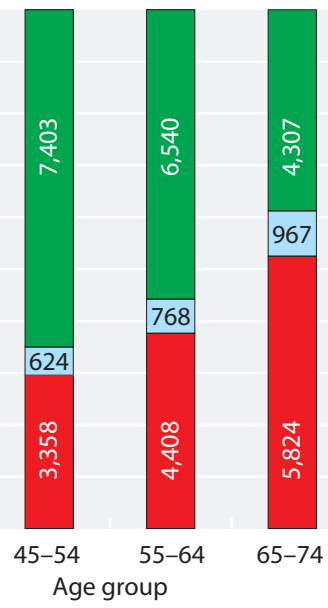

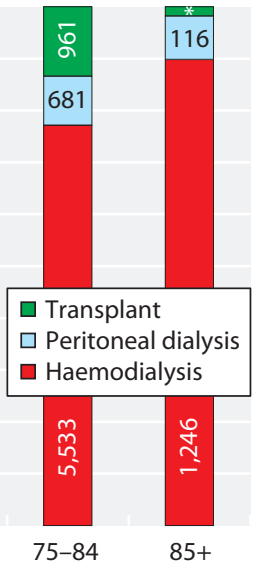

Fig. 2.7. Treatment modality distribution by age in prevalent RRT patients on 31/12/ 2012

${ }^{*} N=25$ 
Table 2.16. Percentage of prevalent dialysis patients by dialysis modality by centre on $31 / 12 / 2012$

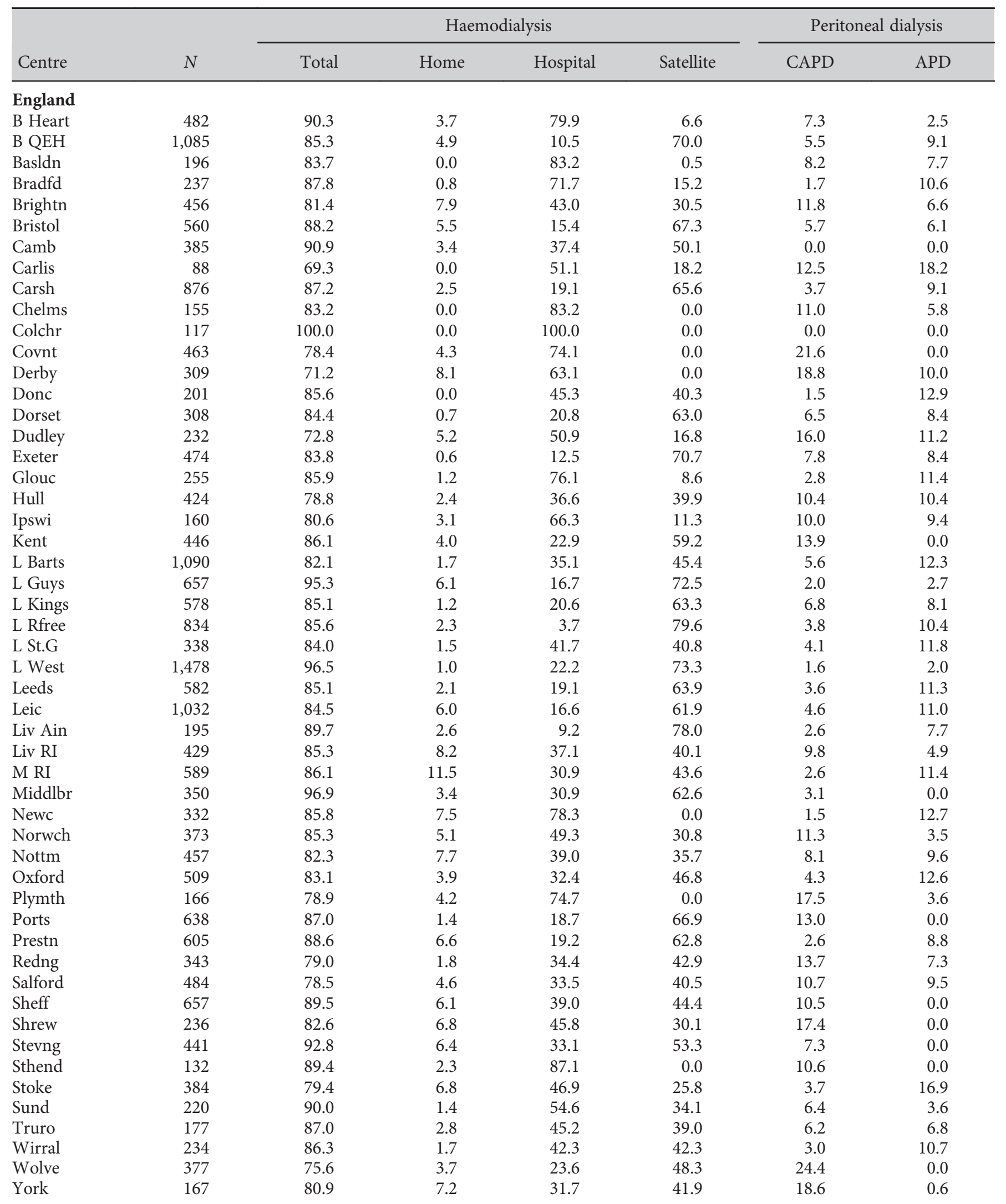


Table 2.16. Continued

\begin{tabular}{|c|c|c|c|c|c|c|c|}
\hline \multirow[b]{2}{*}{ Centre } & \multirow[b]{2}{*}{$N$} & \multicolumn{4}{|c|}{ Haemodialysis } & \multicolumn{2}{|c|}{ Peritoneal dialysis } \\
\hline & & Total & Home & Hospital & Satellite & CAPD & APD \\
\hline \multicolumn{8}{|l|}{ N Ireland } \\
\hline Antrim & 145 & 91.0 & 2.8 & 88.3 & 0.0 & 1.4 & 7.6 \\
\hline Belfast & 256 & 89.1 & 8.2 & 80.9 & 0.0 & 0.8 & 9.8 \\
\hline Newry & 107 & 85.0 & 2.8 & 82.2 & 0.0 & 0.0 & 15.0 \\
\hline Ulster & 116 & 93.1 & 3.5 & 89.7 & 0.0 & 0.0 & 6.9 \\
\hline West NI & 154 & 87.7 & 3.9 & 83.8 & 0.0 & 0.0 & 12.3 \\
\hline \multicolumn{8}{|l|}{ Scotland } \\
\hline Abrdn & 255 & 90.2 & 2.0 & 88.2 & 0.0 & 5.5 & 4.3 \\
\hline Airdrie & 205 & 94.6 & 0.0 & 94.6 & 0.0 & 3.4 & 2.0 \\
\hline D \& Gall & 67 & 76.1 & 1.5 & 74.6 & 0.0 & 11.9 & 11.9 \\
\hline Dundee & 202 & 89.6 & 0.0 & 89.6 & 0.0 & 2.5 & 7.9 \\
\hline Dunfn & 167 & 88.0 & 0.0 & 88.0 & 0.0 & 0.0 & 12.0 \\
\hline Edinb & 302 & 87.8 & 2.0 & 85.8 & 0.0 & 4.0 & 8.3 \\
\hline Glasgw & 671 & 93.0 & 5.2 & 87.8 & 0.0 & 2.4 & 4.6 \\
\hline Inverns & 92 & 80.4 & 7.6 & 72.8 & 0.0 & 7.6 & 12.0 \\
\hline Klmarnk & 191 & 78.5 & 4.2 & 74.4 & 0.0 & 2.1 & 19.4 \\
\hline \multicolumn{8}{|l|}{ Wales } \\
\hline Bangor & 105 & 85.7 & 13.3 & 54.3 & 18.1 & 5.7 & 8.6 \\
\hline Cardff & 559 & 86.2 & 5.4 & 12.7 & 68.2 & 9.3 & 4.5 \\
\hline Clwyd & 102 & 82.4 & 2.9 & 79.4 & 0.0 & 6.9 & 0.0 \\
\hline Swanse & 396 & 82.8 & 7.1 & 47.5 & 28.3 & 14.1 & 3.0 \\
\hline Wrexm & 118 & 81.4 & 0.9 & 67.0 & 13.6 & 18.6 & 0.0 \\
\hline England & 22,993 & 85.8 & 3.9 & 33.4 & 48.5 & 7.1 & 7.0 \\
\hline $\mathbf{N}$ Ireland ${ }^{\mathrm{a}}$ & 778 & 89.2 & 4.9 & 84.3 & 0.0 & 0.5 & 10.2 \\
\hline Scotland ${ }^{b}$ & 2,152 & 89.0 & 2.9 & 86.2 & 0.0 & 3.4 & 7.6 \\
\hline Wales & 1,280 & 84.4 & 5.9 & 37.2 & 41.3 & 11.2 & 3.6 \\
\hline UK & 27,203 & 86.1 & 4.0 & 39.2 & 42.9 & 6.8 & 6.9 \\
\hline
\end{tabular}

${ }^{\text {a }}$ There are no satellite units in Northern Ireland

${ }^{\mathrm{b}}$ All haemodialysis patients in Scotland are shown as receiving treatment at home or in centre as no data is available regarding satellite dialysis

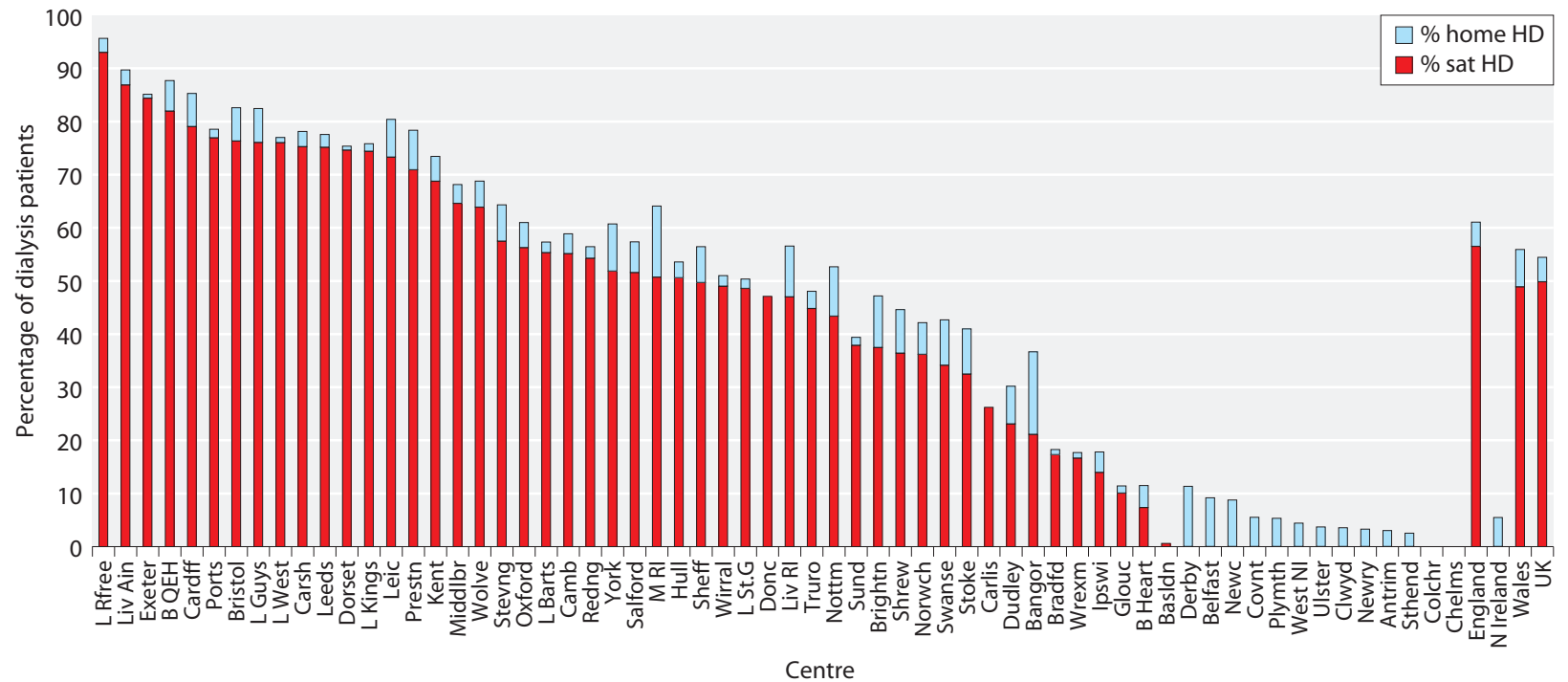

Fig. 2.8. Percentage of prevalent haemodialysis patients treated with satellite or home haemodialysis by centre on $31 / 12 / 2012$ ${ }^{*}$ Scottish centres excluded as information on satellite HD was not available. No centres in Northern Ireland have satellite dialysis units 


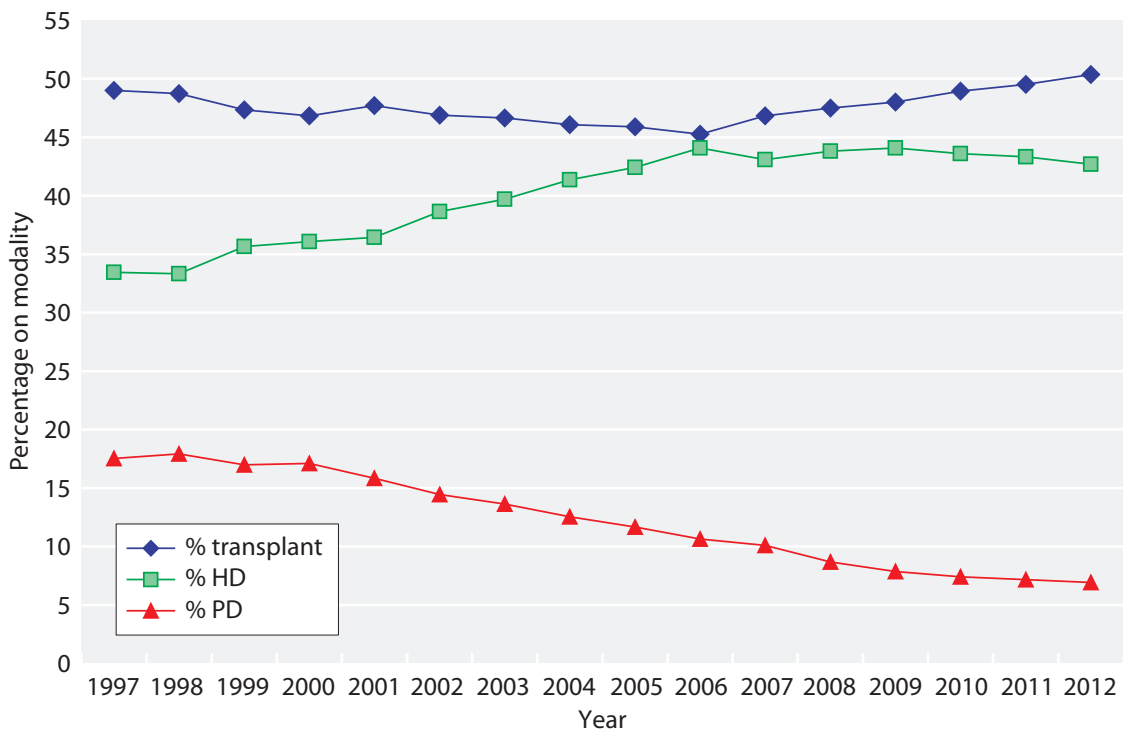

Fig. 2.9. Modality changes in prevalent RRT patients from 1997-2012 plateau, with only a minor reduction from $7.2 \%$ of the RRT population in 2011 to $6.9 \%$ in 2012 . For the first time since 2007, the absolute number of patients on PD increased from 3,780 patients in 2011 to 3,792 patients in 2012. Time on PD has decreased marginally over that last six years, from a median of 2.0 years in 2007 to 1.7 years in 2012 probably reflecting increased transplantation rates in this largely younger patient group.

Since 2009 there have been small increases in the size of the incident population commencing PD as the first established modality. The determinants of this are likely to be multi-factorial and include the effect of patient or physician choice regarding the treatment modality at start of RRT, the general health and fitness of patients starting RRT, organisational level flexibility around PD tube insertion and acute PD. The introduction of dialysis best practice tariffs in England may result in further changes to the types of treatment patients receive in England.

The proportion of patients treated with $\mathrm{HD}$ has stabilised in the last three years. The proportion of patients with a functioning transplant which had been on a slight downward trend has reversed since 2007, probably due to continued increases in living organ and non-heart beating donation [7].

Figure 2.10 depicts in more detail the modality changes in the prevalent dialysis population during this time and highlights a sustained reduction in the proportion of patients treated by CAPD. There was a sustained increase in the proportion of prevalent $\mathrm{HD}$

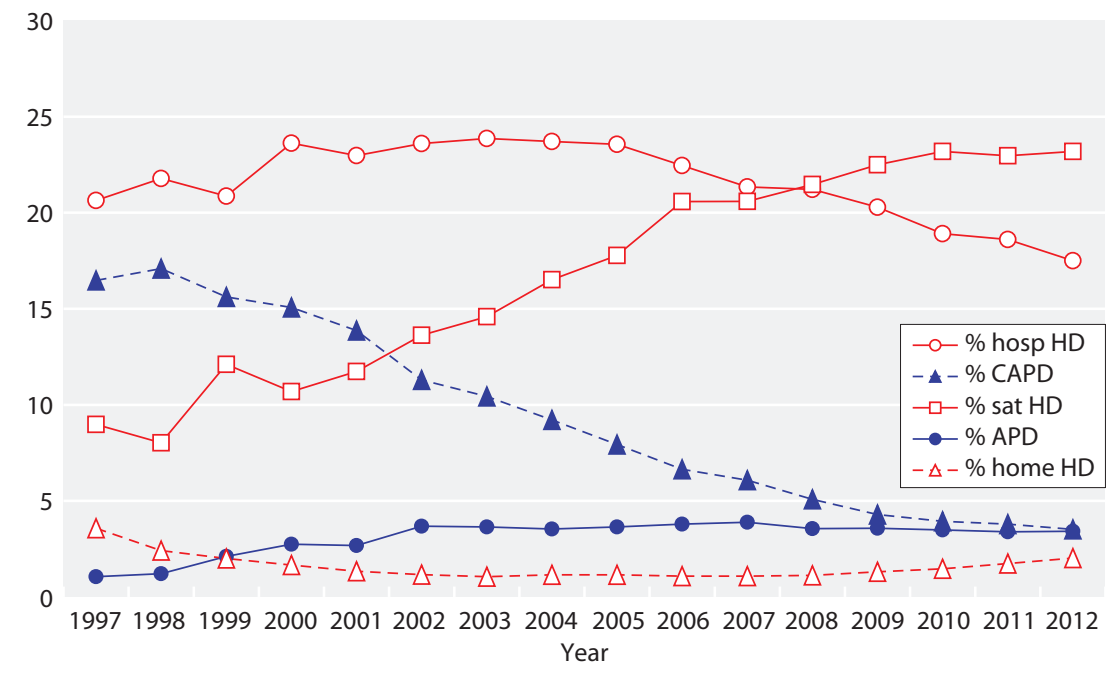

Fig. 2.10. Detailed dialysis modality changes in prevalent RRT patients from 1997-2012

* Scottish centres excluded as information on satellite HD was not available 
patients treated at satellite units with a steady decline in hospital centre haemodialysis since 2004 .

\section{International comparisons}

At the time of writing this report, prevalence rate data were not yet available for 2012 from other countries. Therefore international comparisons of prevalence rates are not presented. This data will be added to the UKRR data portal when it is available.

\section{References}

1 Office for National Statistics. www.statistics.gov.uk

2 National Records of Scotland. http://www.nrscotland.gov.uk/

3 Northern Ireland Statistics and Research Agency. http://www.nisra.gov. uk/

4 Office for National Statistics. The classification of ethnic groups. (www. statistics.gov.uk)

5 Ansell D, Feest T: The sixth annual report. Chapter 17: Social deprivation on renal replacement therapy. Bristol, UK Renal Registry, 2003

\section{Summary}

There continues to be growth across the UK in prevalent patients on RRT with regional and centre level variation. There was no real difference in prevalence rates between the four nations of the UK once adjusted for background population characteristics. In general, areas with large ethnic minority populations had higher standardised prevalence ratios. There were increasing numbers of patients on HD and those with a functioning transplant. There was an absolute increase in patient numbers on PD in 2012, with only a minor reduction in the relative proportion on PD between 2011 and 2012. The prevalence rate in the over 80 year age group continues to increase. There have been substantial increases in home HD use in some areas although several centres are still unable to offer this modality.

Conflicts of interest: none

6 NICE 2002. Technology appraisal No 48. National Institute Clinical Excellence. www.nice.org.uk

7 NHS Blood and Transplant activity report 2009/2010. Transplant activity in the UK. http://www.organdonation.nhs.uk/ukt/statistics/transplant activity_report/current_activity_reports/ukt/activity_report_2009_10.pdf 